Peter J. Boettke

\title{
WHERE DID ECONOMICS GO WRONG? MODERN ECONOMICS AS A FLIGHT FROM REALITY
}

ABSTRACT: F. A. Hayek's realistic economic theory has been replaced by the formalistic use of equlibrium models that bear little resemblance to reality. These models are as serviceable to the right as to the left: they allow the economist either to condemn capitalism for failing to measure up to the model of perfect competition, or to praise capitalism as a utopia of perfect knowledge and rational expectations. Hayek, by contrast, used equilibrium to show that while capitalism is not perfect, it contains error-correcting institutions that bring it closer to perfection than is intuitively apparent.

On March I, I933, F. A. Hayek delivered his inaugural lecture at the London School of Economics and Political Science. Hayek, recently appointed to the Thomas Tooke Chair in Economic Science and Statistics at the LSE, sought to explain the trend in public opinion toward economic interventionism, embodied in the para-

Critical Review II, no. I (Winter I997). ISSN 089I-38II. (C) I997 Critical Review Foundation.

Peter J. Boettke, Department of Economics, New York University, 269 Mercer Street, New York, NY IOOO3, telephone (2I2) 998-8900, e-mail boettke@fasecon.econ.nyu.edu, the author of The Political Economy of Soviet Socialism (Kluwer, I990) and Why Perestroika Failed (Routledge, I993), thanks Tyler Cowen, Jeffrey Friedman, Steven Horwitz, Israel Kirzner, Daniel Klein, David Prychitko, Mario Rizzo, and Edward Weick for their comments and suggestions, and gratefully acknowledges financial assistance from the National Fellows Program of the Hoover Institution on War, Revolution, and Peace, and from the Sarah Scaife Foundation in support of the Austrian Economics Program at NYU. Earlier versions of this paper were presented at the History of Economic Society meetings at the University of Notre Dame, June I995; the Austrian Economics Colloquium at New York University, March I993; and Central European University, Prague, January I993. 
dox that questions about economic matters were asked more frequently than questions related to any other academic discipline, even while the answers economists gave were largely disregarded by a skeptical public.

The cause of this paradox, according to Hayek, was twofold. First, the teachings of economics are counterintuitive. (Who would intuit that a law to raise wages might instead cause unemployment?) Second, these teachings expose as utopian many commonsensical solutions to concrete problems. "The existence of a body of reasoning which prevented people from following their first impulsive reactions, and which compelled them to balance indirect effects, which could be seen only by exercising the intellect, against intense feeling caused by the direct observation of concrete suffering, then as now, occasioned resentment" (Hayek I933, 2I).

This resentment, Hayek argued, coupled with recent re-examinations of the analytical foundations of classical economics, had provided fertile ground for the German Historical school to rise to prominence among economists. The German school, along with American Institutionalism, offered a method for the practicalminded economist that did not possess the frustrating features of classical analytical economics. A body of thought that justified treating economic problems as unique-and their solutions as unbound by economic principles-was welcome relief for the wouldbe economic reformer.

The full effect of this trend, Hayek argued, was only being felt within the second generation of economists subject to its influence. The first generation, while rejecting the analytical method of classical economics, was nevertheless trained in it. Although they tried to shake off the rigorous logic of the classical school, economists trained in that way of thinking could not fully escape its influence. The second generation, however, not trained in the classical method, lacked the mental tools necessary to interpret economic phenomena in a theoretically coherent manner.

Hayek's argument can cut two ways, as I will try to demonstrate throughout this essay. On the one hand, Hayek was certainly right to suggest that the attempt to reject economic theory in the name of "realism" was inimical to satisfactory economics. We have no choice but to think in terms of models and simplifying assumptions. The world would be too complex to understand otherwise. But, on the other hand, the proposition that all thought is framed 
by theoretical concepts (whether consciously or unconsciously adopted) and, as a result, that all facts are theory-laden, does not license the adoption of any and every theory. Some theories are better than others. Hayek left this side of the argument unexamined. For his purposes, it was enough to contrast theory with Historicism and maintain that theory is essential for proper economic analysis and public policy application.

Internal coherence is one way of adjudicating among theories, but so is correspondence to everyday life. Too much realism may kill analysis, but too little realism is unscientific. If theoretical coherence alone were all that mattered, then the only constraint on theoretical exercises would be the human imagination. Interesting puzzles would replace pragmatic solutions to problems encountered in the world - arguably, an accurate characterization of most contemporary economic theory. Economists must steer a course between (allegedly) pure description and the mere recording of events, on the one side, and self-indulgent mental gymnastics on the other. In 1933, Hayek addressed himself only to the problems associated with putatively unvarnished historical description.

The task of the economist, according to Hayek, was to construct from familiar elements, gleaned from our everyday experience in the world, a mental model aimed at reproducing the workings of the economic system. This task was misunderstood by economists of his day, he argued, because the self-organizing principles of the market economy were no longer understood. These principles were the great contributions of classical economics. But by the time neoclassical economists responded to the Historicist challenge by developing marginal analysis, it had been too late. The generation of economists now entrusted with designing public policy had lost an understanding of the basic properties of the market system. As a result, the trend in economic thinking was biased toward government planning of the economy. This trend was not only reflected in the growing interest in socialism, but could also be detected in the reemergence of arguments for protectionism in international trade and for regulation of the domestic economy.

\section{WHERE HAYEK WENT WRONG}

Hayek's lecture is of interest to us today mainly for its early statement of themes that later came to dominate his research program. 
As Bruce Caldwell puts it, Hayek's lecture, although entitled "The Trend of Economic Thinking," "is probably best viewed as a suitable point of departure for explicating the trend of Hayek's thinking" (Caldwell I988, I78). Hayek was prescient about the policy direction that would increasingly dominate economic thought, but he blamed the wrong forces for this trend. Historicism and Institutionalism, along with Hayek's own Austrian school of economics, were to be completely displaced by formalism within the decade following Hayek's address. Interventionism and planning would be justified not on Historicist grounds, but on the basis of the most advanced refinements of economic theory and technique that neoclassical economics - the very brand of economics Hayek tried to defend-had to offer.

The Austrians' theoretical arguments, however, soon came to be excluded from the canon of neoclassical "theory" by mathematical formalists, even while the empirical investigations of the American Institutionalists and the German Historicists were not considered "empirical" after the parallel development of modern statistical techniques by econometricians (Caldwell I989). The discipline of economics rejected both the Austrian and the Historicist/Institutionalist traditions of economic thought, yet reached nearly the same interventionist conclusions that the Historical and Institutionalist schools favored.

This was hardly the trend that Hayek detected in his inaugural address at the LSE. Nor was Hayek the only member of the Austrian school about to be blindsided by the direction of economics. Ludwig von Mises wrote in 1933 that there were no substantive differences between the various schools of modern neoclassical economics (Mises I98I, 2I4). He viewed Austrian economics as squarely within the mainstream of neoclassical thought, the tradition identified by Hayek as yielding propositions that flew in the face of the simplistic intuitive appeal of government intervention and planning. For Mises, much as for Hayek, the enemies of modern economic science were Marxism, Historicism, and Institutionalism. Subtle differences in theory and the mode of its presentation among mainstream neoclassical economic theorists did not matter much, not when compared to this major division. Neoclassical economics-classical economics grounded in marginal utility theorywas scientific; other approaches were pseudoscientific.

Hayek's and Mises's myopia notwithstanding, among neoclassical 
economists the Austrians were indeed different. The Viennese economist Carl Menger and those following in his footsteps emphasized, in addition to subjectivism and marginal utility analysis, the role of knowledge and ignorance, time and uncertainty, change and disequilibrium in understanding economic processes. Austrian and Swedish economists (and a few Americans and Britons, such as Frank Fetter and Philip Wicksteed) aside, neoclassical economists ignored these matters in their theorizing. But because Austrian economists agreed with the mainstream about the value of subjective utility and marginal analysis, they were viewed by the others, and more importantly by themselves, as indistinguishable from mainstream economists who overlooked market "imperfections" such as time and ignorance. ${ }^{1}$

Hayek and Mises failed to see what was coming because the tension between neoclassical and Austrian economics only became acute during two economic debates that had not yet begun: one with John Maynard Keynes over macroeconomic theory and policy, and the other with Oskar Lange over the feasibility and desirability of socialism. Even the debate with Keynes was not, alone, enough to disturb the Austrians' vision of their school's "mainstream" status. In reality this debate revolved around fundamental issues in money and capital theory, but on the surface it was about more superficial questions of public policy. This was obscured, on both sides, by the fact that Hayek's brand of Continental capital and monetary theory was little understood and appreciated in England and America. John Hicks pointed out that while Hayek wrote in English, it was not English economics (Hicks I967). As a result, many of the analytical issues at stake were never adequately addressed.

Keynes, for example, never successfully responded to Hayek's critique of his Treatise on Money, in which Hayek questioned Keynes's tendency to treat real economic factors as aggregates, and criticized Keynes's failure to provide a theory of capital. The debate was a case study in mutual misunderstanding. Since Hayek shared the basically laissez-faire policy conclusions of many classical British economists, Keynes associated Hayek, incorrectly, with the British anti-interventionists' theoretical apparatus-which Hayek had (albeit unwittingly) jettisoned, at least in part. In this manner, Hayek was lumped by Keynes with the "classical" school that was to be overturned by The General Theory of Employment, Interest and Money. By the same token, according to the Austrians all that was needed 
to demonstrate the fundamental problems with Keynes was classical economics; for Keynes's General Theory was interpreted by Mises and Hayek as a return to the inflationist fallacies of the past (which even crude versions of the quantity theory of money had displaced) and to an economics of abundance, which denied that capital resources were scarce. But here the Austrians were mistaken. ${ }^{2}$ Certainly Keynes made fundamental errors in economic reasoning, but in many other respects, he had penetrated classical British economics deeply and had left it in tatters. Appeals to economic orthodoxy were not enough, either rhetorically or substantively, to forestall the rush to embrace Keynesian economics and policy. ${ }^{3}$

The Great Depression not only led to the embrace of Keynesian economics, it also lent new prestige to socialism. Capitalism, critics argued, was both unjust and chaotic. Business cycles were seen as manifestations of the inherent contradictions of capitalism. This message possessed a very practical appeal during the crisis, for obvious reasons.

Nothing in the popular version of this socialism would have shaken the self-image of Austrian economists as members of the economics mainstream. As early as the I890s, Eugen von BöhmBawerk had used neoclassical economic theory to rebut Marx's understanding of the operation of capitalism. In I920, Mises did the same thing for the idea of socialist economic planning, demonstrating that without private ownership in the means of production, socialist planners could not rationally calculate the alternative uses of scarce resources (Mises 1920 and 1922). But in the I930s, Oskar Lange used neoclassical equilibrium analysis to demonstrate that Mises's criticism was not valid-if one assumed that perfect knowledge was available to the planners. For in that case, they could calculate the alternative use of resources just as the competitive market supposedly does, through a process of trial and error. Socialist planners would draw on knowledge of supply and demand conditions in the same manner that economic agents within a market economy were pictured as doing in the neoclassical model of the perfectly competitive economy in equilibrium. If this model was theoretically coherent, then Lange's model of market socialism was equally coherent.

Lange's defense of socialism on neoclassical grounds took the Austrians by surprise, as did its acceptance by mainstream economists. Such established figures as Frank Knight and Joseph Schum- 
peter concurred with Lange's assessment of the analytical issue, and younger economists, such as Abba Lerner, began to develop Lange's argument further. In response, both Mises and Hayek started to articulate more clearly and precisely what differentiated Austrian economics from the neoclassical orthodoxy. But by this time they were already too far outside of the mainstream to command its attention any longer. Mises and Hayek came increasingly to be viewed as politically motivated pundits of the right, not as serious economists. By I950 at the latest, the Austrian school of economics was forced underground-to the extent that, by now, it is questionable whether it should be considered part of the discipline of economics any more. By mid-century Hayek's prediction had came true: interventionism, even socialism, came to dominate economics. But the source of this trend was not antitheoretical Historicism. It was neoclassical theory itself.

\section{THE FORMALIST REVOLUTION}

In the eyes of professional economists, Austrian economics was soundly defeated by both Keynesianism and neoclassical socialism. Whereas Keynesianism challenged the macroeconomic stability of capitalism, neoclassical socialism challenged its microeconomic efficiency. Lange and Lerner's argument could be interpreted as demonstrating that ideal market socialism could perform as well as ideal capitalism. A stronger interpretation, however, was that in the face of allegedly widespread monopoly power in real-world capitalism, real-world market socialism would be even more efficient.

What made the neoclassical mainstream receptive to these ideas was its failure to take seriously such factors as the use of (and imperfections in) economic knowledge, the presence of ignorance and uncertainty, the passage of time, and changes in economic conditions. All of this was assumed away in mainstream equilibrium models. Meanwhile, Austrians continued to uphold the counterintuitive policy conclusions of earlier economic theory because, if one did take these factors seriously, new forms of interventionism premised upon perfect knowledge in a timeless, changeless equilibrium seemed utterly fantastic, hence irrelevant.

Austrians, for example, argued that monetary inflation worked its way through the economic system by means of a ragged process of relative price adjustment. Thus, the nominally unimportant effect 
of inflation on money prices could have very real effects on the underlying distribution of resources: relative price signals could become distorted, misleading investors. The injection of money into one sector of the economy could create the illusion of increased real demand there, leading to unneeded new investment. Moreover, investment required resources that, far from being an undifferentiated aggregate, "capital," were both heterogeneous and specific to certain projects. The capital needed to build a house is different from that needed to build a car. Distortions in investment caused by monetary disturbances in the price system could therefore have severe consequences. Blinded by its maintenance of a stable supply of "capital," the government could overstimulate the supply of, for instance, houses at the expense of what consumers actually wanted, such as cars. Mainstream neoclassical economics, however, overlooked these problems either by rejecting the quantity theory of money altogether, as Keynesians did; or else by accepting the Monetarists' crudely mechanical version of it, which took evenly proportionate adjustments in the general price level to be the main consequence of increases in the money supply. The theoretical and methodological work of Mises and Hayek, which emphasized processes of adjustment to real-world changes in the "data" that the mainstream saw as given and unproblematic, appeared anachronistic to economists whose attention was focused on an imaginary state of equilibrium, whether perfect or imperfect (i.e., marred by unemployment).

In 1947, the gap between the Austrians and the mainstream of neoclassical economics was widened by the publication of Paul Samuelson's Foundations of Economic Analysis. ${ }^{4}$ Samuelson pioneered a synthesis of neoclassical and Keynesian economics, as well as endorsing the Lange-Lerner argument for market socialism. ${ }^{5}$ Samuelson also furthered the neoclassical case against the free market in the I950s, with his development of the theory of market failure.

Previously, the model of a perfectly competitive market was primarily used in thought experiments designed to be contrasted with real-world market institutions. Such counterfactual thought experiments illuminated the positive function of those institutions (e.g., Knight I92I). In a world of complete information, for example, neither firms nor profits would logically exist. Therefore, the constrast of this imaginary world against the real world of firms and 
profits showed that such institutions may have some functional significance in coping with imperfect and incomplete information.

This counterfactual use of the theory of perfect competition was reversed by the formalist revolution in economics. ${ }^{6}$ The departures of reality from the model of perfect competition were now thought to highlight interventions in the market economy that would be necessary to approximate equilibrium. Competitive equilibrium and the maximizing behavior that would ideally produce it represented the hard core of the research program of economists from I950 on. As this happened, economics as a discipline was transformed. ${ }^{7}$

The central role the model came to play was independent of whether it was employed by the minority who thought the market economy approximated the model, or the majority who thought that capitalism deviated significantly enough from the model that a great deal of government intervention was justified. In both cases, formalism led to utopianism. Either (in the minority view) reality was idealized, so that it approximated the model; or (in the majority view) reality became a dystopia, devoid of dynamic adjustment properties, and utopian properties were inadvertently attributed to interventions designed to make reality match the model. Absent from both types of formalism was recognition of any possibility other than all or nothing. Either the real world exemplified static equilibrium, or it could not approach that state without a push from the state. The intermediate possibilities represented by realworld institutions of adjustment to disequilibrium became invisible because the model contained only equilibrium.

Competitive equilibrium required: (I) perfect information, (2) large numbers of buyers and sellers, and (3) costless mobility of resources. Under this set of restrictions, the logic of the model determined (4) that each market participant would treat prices as given, and (5) that prices would equal the marginal costs of production. As a result, firms would produce at minimum average cost and earn zero economic profits. In the I950s and I960s, mainstream theory produced two fundamental welfare theorems that followed from proofs of the (mathematical) existence and stability of this competitive equilibrium. The first welfare theorem stated that an economy in competitive general equilibrium was Pareto efficient. The second theorem stated that any desired Pareto-efficient economy could be achieved through the decentralized market mechanism. Together, 
these two welfare theorems prove that if the appropriate conditions hold, the market mechanism yields the best possible economy.

That, however, is a big if. Without perfect futures markets, for example, intertemporal allocations could not be assumed to be optimal. Unless the strict conditions required for general competitive equilibrium were met, the economic theorist could not with any confidence make pronouncements about the efficiency of market allocations. In fact, she could be confident that the market would yield suboptimal results that demanded corrective government action.

The new role played by competitive equilibrium was fostered by Samuelson's methodological innovations. Samuelson sought to rewrite economics into the language of mathematics so as to eliminate the vague assumptions that underlay debates among "literary economists" of previous generations. Restating economics in the axiomatic language of mathematics, Samuelson argued, would force economists to make explicit assumptions that they had previously held implicitly. But the techniques of mathematics available to Samuelson required well-behaved and linear functions; otherwise, results would be indeterminate and the promised precision would not be achieved. In order to fit economic behavior into mathematical language, the real world had to be drained of its complexity. The problem situation of economic actors had to be simplified drastically so as to yield the precise formulations Samuelson sought.

Samuelson's research program eliminated the conscious component from the economic choices facing individuals in a world of uncertainty. Choice was reduced to a simple determinate exercise within a given ends-means framework, something an automaton could master. The task of discovering not only appropriate means, but also which ends to pursue, was left out of the equation. Moreover, it was forgotten that market institutions and practices arise in large part precisely because of deviations from the perfect-market model. Just as the friction between the soles of our shoes and the sidewalk enables us to walk, the imperfections of the real world give rise to the essential institutions and practices that make economic life possible. The complexity of both institutions and individuals is impossible to model precisely, so it was pushed aside by simplifying assumptions.

The huge gap between the older view preserved in Austrian economics and the new use of equilibrium models can be illus- 
trated by considering the reception of Ronald Coase's work on transaction costs. Viewed as a practitioner of counterfactual thought experiments, what Coase was focusing on (in both his I937 paper on the theory of the firm and his 1960 paper on the problem of social costs) was the origin of actual market and legal institutions as mechanisms for coping with real-world positive transaction costs (see Coase 1988). Without transaction costs, Coase argued in I937, there would be no need for firms. Transactions in spot markets would be all that would be necessary to coordinate production. In addition, without transaction costs, Coase argued in I960, there would be no need for property law. Voluntary negotiations between economic actors would resolve all conflicts over property rights. The actual existence of firms and the law can be seen, therefore, as evidence of the ubiquity and intractability of transaction costs.

Coase's project, however, has been largely misunderstood by formalist neoclassical economics. Instead of highlighting the functional significance of real-world institutions in a world of positive transaction costs, Coase's work has been interpreted as describing the welfare implications of a zero-transaction-cost world. The "Coase Theorem" has been taken to hold that in a world of zero transaction costs, the initial distribution of property rights does not matter; for as long as individuals are free to transact, resources will be channelled toward their most highly valued use. ${ }^{8}$

Coase's theoretical insights into the role of institutions of property and contract, however, were not all that was buried by the formalist revolution. Historical work on the complex web of institutions that undergird capitalist dynamics produced by the earlier generation of neoclassical scholars, such as Knut Wicksell, Frank Knight, and Jacob Viner, as well as Mises and Hayek, was swept aside in the rush toward formal theorizing. The real problem with the trend in economic thinking in the I930s and I940s was neither the critique of theory carried on by Historicism and Institutionalism, nor the war against classical liberalism launched by Keynesians and socialists. The antitheoretical stance of Historicism and Institutionalism was self-defeating, and Keynesianism and socialism would rise and fall with the tides of politics. The real problem for economics was that the medium was becoming the message, as the strictures of formalism denied scientific status to realistic theory.

Ideas that defied the techniques of formal analysis came to be considered unworthy of serious consideration. Even when an idea 
was thought to be interesting, if it could not be translated into an appropriate model, there was not much that could be done with it. ${ }^{9}$ The substance of economics was displaced by mathematical technique, and fundamental economic knowledge was set backdespite the obvious progress made in the precision with which economists could say what was left to say. ${ }^{10}$

The first casualty of the formalist revolution was the historically and institutionally rich tradition of economics still evident in the I930s. Case studies of particular industries, for example, had been common. After the development of econometrics, however, the case-study approach was discarded in favor of large-sample data analysis. The second casualty of the formalist revolution was what might be called "the economist's way of thinking," the defining characteristic of the discipline in both its classical and early neoclassical renditions. The best of the earlier economics combined an appreciation for the particularities of institutional context with theory grounded in the generalities of choice under conditions of scarcity. Individuals always face tradeoffs, in this view, but the manner in which they weight their choices is contingent upon the particular context of choice.

Samuelson drained economic theory of institutional context, and the econometric approach to empirical economics eliminated historical detail. Parsimony won out over thoroughness. Economics moved at this time from one side of the cultural divide (the liberal arts) to the other side (the sciences) - or at least that was the selfimage of economists, who equated science more with precision than accuracy. The physicist does not allow the impossiblity of making accurate predictions in many real-world contexts (such as meteorology) interfere with her pursuit of the precise formal laws that govern them. By myopically pursuing only the formal aspects of the discipline, economics was reduced to its present state, in which we continually know more and more about less and less. ${ }^{11}$

\section{EQUILIBRIUM: DESCRIPTION OF REALITY, NORMATIVE CRITIQUE, OR IDEAL TYPE?}

In light of the formalist revolution in economic theory, we can usefully distinguish the older use of the equilibrium model as an ideal type from its use by free-market Chicago-school economists as a 
description of reality, as well as its use by interventionist Neo-Keynesians as a critical standard with which reality could be indicted when it failed to measure up. In the latter two uses of equilibrium, it constitutes a static ideal, and the question is whether reality does or does not match it. In the ideal-type use, by contrast, the question is how departures from the ideal type-denied by the Chicago school; equated with market "failure" by Neo-Keynesians-may constitute forms of incomplete success. An ideal type is neither intended to describe reality nor to indict it. It is instead a theoretical construct intended to illuminate certain things that might occur in reality; empirical investigation determines whether these phenomena are actually present and how they came to be there. ${ }^{13}$ In this view, disequilibrium is not necessarily a market failure; something less than perfection may yet be better than any attainable alternative.

Deployed as an ideal type, equilibrium analysis allowed economists to describe what the world would be like in the absence of imperfections such as uncertainty and change. The descriptive value of the model lay precisely in its departure from observed reality, for this underscored the function of real-world institutions in dealing with imperfect knowledge, uncertainty, and so forth. Equilibrium was used as an ideal type by such Austrian economists as Mises and Hayek; early Chicago-school theorists, such as Frank Knight; LSE theorists, such as Coase; and Swedish-school theorists, such as Knut Wicksell. By contrast, economic formalism was, at first, virtually defined by the use of equilibrium as a standard for criticizing reality that, on the one hand, ignored its dynamic elements and, on the other, assumed that static perfection must (somehow) be attainable. Samuelson, Kenneth Arrow, Frank Hahn, and more recently Joseph Stiglitz are the major theorists who have employed equilibrium models in this manner.

Almost simultaneously with the emergence of equilibrium as an indictment of reality, University of Chicago economists such as Milton Friedman, George Stigler, Gary Becker, and Robert Lucas began to use it as a description of reality. In their view, real markets come breathtakingly close to approximating the efficiency properties of general competitive equilibrium. And even if a real-world market deviates from the ideal, the predictions of the model approximate behavior in the real world better than alternative models do. Real-world markets, in other words, act "as if" they were in 
competitive equilibrium. In fact, Becker and Lucas treat the existence of equilibrium as an explicit core assumption of their analysis of economic phenomena. By collapsing the gap between the model and reality, the Chicago school in its purest form does away with the need for intervention of the sort advocated by Samuelson et al. Hence the current reputation of laissez faire as a wildly unrealistic economist's dogma. In comparison with the implausible assumptions of Chicago-school laissez faire, government regulation has come to be seen not as a utopian outgrowth of crude, "intutive" economic thought, but as a form of hard-headed realism.

From the perspective of those who see equilibrium as an ideal type, both its empirical idealization and its use as an indictment of a static reality appear deficient. The Chicago school's use of equilibrium to describe reality conflates the mental and empirical worlds. And while those who use equilibrium to indict reality recognize that the world is not perfect, their ignorance of the ways imperfect institutions do produce a semblance of economic order gives them an unduly pessimistic view of the market, and an unrealistically optimistic tendency to rely on legal fiat to bring reality up to par. In both cases, the heuristic value of equilibrium is sacrificed. By ignoring the dynamics of disequilibrium, both traditions obscure the possibility that real-world market institutions may have coordinative properties even in the presence of dispersed knowledge, pervasive ignorance, the irreversibility of time, and changing conditions. ${ }^{14}$ While the descriptive use of equilibrium readily leads to an endorsement of market transactions, it does so on an unrealistic basis. The proof is that the Chicago school lacks a theory explaining how markets achieve whatever degree of success they do; all the important work, as critics never tire of pointing out, is done by the model's assumptions. Similarly, the use of equilibrium as an indictment of reality fails to allow that existing imperfections may, in a dynamic world, be a source of motivation and learning that leads to the correction of market errors.

Both predictive and normative uses of equilibrium portray markets as essentially static. This constitutes an unwitting rejection of the heart of Hayek's contribution, despite the lip-service often paid by formalist economists to his seminal essays on "Economics and Knowledge" (1937) and "The Use of Knowledge in Society" (I945). ${ }^{15}$ 


\section{IV. “INFORMATION” AS A BRIDGE TO REALITY}

The central concern of economics, Hayek suggested, is to explain "how the spontaneous interaction of a number of people, each possessing only bits of knowledge, brings about a state of affairs in which prices correspond to costs, etc., and which could be brought about by deliberate direction only by somebody who possessed the combined knowledge of all those individuals." Economic theory, in other words, should explain observed reality. The empirical observation that prices do tend to correspond to costs is the starting point of economic science. But formal neoclassical theory, instead of discerning how diffuse information is processed and used by imperfect economic actors, falls "back on the assumption that everybody knows everything" and so evades "any real solution of the problem" (Hayek [1937] I948, 50-5I).

Hayek went further, arguing that the kind of knowledge that is dispersed among market participants is "knowledge of the kind which by its nature cannot enter into statistics" (Hayek [1945] I948, 83). The content of market prices is not the sort of information that can be treated as a commodity. It is not, therefore, the costliness of information that is essential to Hayek's story, but rather its dispersal. Its dispersal makes economic knowledge inaccessible except under special, institutionally fragile, circumstances. The relevant economic knowledge, as Hayek put, is knowledge of "particular time and place" (ibid., 80). It can only be used and discovered in particular institutional contexts-contexts that are abstracted away in the timeless, placeless formalism of equilibrium modelling. Hence the irrelevance of contemporary economics for comparing the effects of alternative real-world institutional arrangments on actual economic performance. ${ }^{16}$

The fundamental purpose of economic analysis, once Hayek's view of economic knowledge is accepted, is to determine how a dynamic system of production utilizes dispersed knowledge of time and place in a manner that aligns production plans with consumption demands. The money-price system, within an institutional environment of well-defined and enforced private property rights, serves this aligning function in at least three ways. First, ex ante, prices transmit knowledge about the relative scarcities of goods to various market participants so they may adjust their behavior accordingly. If the price of a good goes up, this informs economic ac- 
tors that the good has become relatively more scarce and that they should economize on its use. For this reason, participants in the market have an incentive to include the knowledge contained in prices in their actions over time. Second, the price system serves the ex post function of revealing the ultimate profitability or unprofitability of economic actions. Prescient entrepreneurship (in the broad sense of the term) is rewarded with profits; errors are penalized by losses. Market prices, therefore, not only motivate future decisions by conveying information about changing market conditions, but also help market participants evaluate the appropriateness of past market decisions and correct erroneous ones.

Seen in this light, the market process is a matter of dynamic adjustment. What is it adjustment to? It is, in effect, adjustment to the gaps between a static equilibrium of universal satisfaction and the many departures from this model that are present in the real world. Each of these gaps between the counterfactual and the factual represent a profit opportunity. Price information is also motivation for profitable real-world adjustment, over time, to the profit opportunities of a particular place. ${ }^{17}$

Formal equilibrium theory contains only a distorted, static image of these aspects of the price system. As they came to recognize this deficiency in mainstream neoclassical economics, Hayek and others in the Austrian tradition sought to explain how the price system works in real-world disequilibrium. ${ }^{18}$ The Austrian critique of the standard model is that it has no place for the multifaceted role that disequilibrium prices serve within the market process.

The very idea of an economic theory of the market process stands in contrast to the static nature of equilibrium analysis. Since only an array of disequilibrium prices sets in motion the competitive process characterizing real-world markets, the formalist orthodoxy, by its very nature, must ignore this process. As Mises wrote:

The activities of the entrepreneur or of any other actor on the economic scene are not guided by considerations of any such thing as equilibrium prices and the evenly rotating economy. The entrepreneurs take into account anticipated future prices, not final prices or equilibrium prices. They discover discrepancies between the height of the prices of the complementary factors of production and the anticipated future prices of the products, and they are intent upon taking advantage of such discrepancies. (1949, 329) 
Prices serve as the basis of economic calculation only in the context of a process of competition brought into being by what formalism assumes a way: disequilibrium. Real-world market prices do not perfectly contain all of the relevant information required for competitive equilibrium; if such information were known already, there would be no need for economic activity in the first place. Under disequilibrium conditions, however, the active bidding up of prices when demand exceeds supply, and their bidding down when supply exceeds demand, generates the incentives and information necessary to coordinate economic decisions. The discrepancy between the current array of prices and the anticipated future array of prices provides the incentive for entrepreneurs to discover hithertounknown opportunities for economic profit. Of course, in this process of perceiving the future, entrepreneurs may (and do) make errors, but these errors can, by creating further discovery opportunities, generate further activity aimed at allocating or reallocating resources in a more effective manner to obtain the ends sought after. "The market process," Israel Kirzner writes, "emerges as the necessary implication of the circumstances that people act, and that in their actions they err, discover their errors, and tend to revise their actions in a direction likely to be less erroneous than before" (I979, 30). While the assumption of perfect knowledge was essential for modelling the state of competitive equilibrium, it precluded an examination of the path by which adjustment toward equilibrium could be achieved. If the system were not already in equilibrium, one could not explain how it would get there. Omniscience logically results in non-action. A profit opportunity that is known to all can be realized by none. Thus, if it is to be realistic, the model's assumptions have to be relaxed, but then it becomes overly complex and loses its formal elegance.

This dilemma has dogged a significant strand within the mainstream of economic thought that, since about I960, has tried to take up Hayek's challenge and examine the informational aspect of markets. This research program is of vital importance in evaluating the current state of economics not only because it is the rising orthodoxy at the moment, but because it attempts to grapple with the main feature of reality that, in the Austrian view, is obscured by economic formalism. But because the new economics of information is itself formalist in its use of equilibrium models, it has been 
fated to oscillate between utopianism about the informational properties of real markets and utopianism about the alternatives.

Classical economics had focused exclusively upon the incentive to purchase more or less of a particular good that prices provided. The new economists of information recognize that prices serve a communicative function as well. They see that prices transmit vital knowledge about (for instance) relative scarcities, enabling economic participants to coordinate their decisions. Chicago's George Stigler is usually credited with being the first economist to develop an informational model consistent with standard neoclassical price theory. Stigler (I96I) argued that individuals will optimally search for the information necessary to accomplish their goals in the market, but unlike Hayek, he assumed that they will do so in an optimal manner by comparing the marginal cost of information with the marginal benefit of continuing to search for it. In other words, Stigler joined the informational content of markets with the assumption that equilibrium models should be seen as describing actual behavior. In Stigler's view, there was economic ignorance in the real world, but it was the optimal level of ignorance. The attempt to eliminate the remaining ignorance would entail searches for information that were more costly than the benefits they could produce.

Following Stigler, economists such as Armen Alchian and Jack Hirshleifer developed information-search models in which various aspects of the economic system such as advertising, middlemen, unemployment, queues, and rationing take on a new meaning and functional significance. ${ }^{19}$ At the same time, economists who treated equilibrium as a critical norm rather than a reality, such as Kenneth Arrow, Leonid Hurwicz, and Roy Radner, also sought to develop models that accounted for informational imperfections. ${ }^{20}$ Where Stigler's approach extended the assumption of maximizing behavior to the information-search process, predicting that markets would see various practices emerge to economize on the search process and generate an optimal flow of information, the Arrow/Hurwicz/Radner approach argued that in the face of incomplete information, maximizing agents would be unable to coordinate their behavior with others in an optimal manner unless an appropriate mechanism could be designed anterior to the market. ${ }^{21}$ The first approach presupposed the efficiency of market allocations, the second their inefficiency and the prevalence of market failure. Neither 
approach adequately dealt with disequilibrium or the multi-informational components of market processes that help economic actors adjust to and learn from disequilibrium.

Among contemporary economists, Joseph Stiglitz and Sanford Grossman have elaborated the second approach more systematically than anyone else. Their research on the informational role of prices has led to a fundamental recasting of many basic questions in orthodox economic theory. ${ }^{22}$ Grossman and Stiglitz understand Hayek to be arguing that prices are "sufficient statistics" for economic coordination, and they conclude that this argument is flawed. In situations where private information is important, they contend, market prices will be informationally inefficient, for the market will not provide the appropriate incentives for information acquisition; thus, the case for economic decentralization is not as theoretically strong as Hayek suggests.

Grossman and Stiglitz's reasoning, however, begs the question against Hayek by starting from the unrealistic assumption of rational-expectations equilibrium. Given this assumption, they maintain, prices will reveal information so efficiently that no one could gain from the revelation of privately held information. ${ }^{23}$ Individual agents can simply look at prices and obtain free what would be costly to acquire privately. This free riding leads to an underproduction of information by the market. Prices, as a result, will necessarily fail to reflect all the available information. Grossman (I976, 585) states the supposed paradox as follows:

In an economy with complete markets, the price system does act in such a way that individuals, observing only prices, and acting in self interest, generate allocations which are efficient. However, such economies need not be stable because prices are revealing so much information that incentives for the collection of information are removed. The price system can be maintained only when it is noisy enough so that traders who collect information can hide that information from other traders.

This paradox does challenge Stigler's model of information searching, as well as the traditional welfare theorems of general competitive equilibrium when they are viewed as describing the decentralized price system. But long before Grossman and Stiglitz, Hayek recognized that the first and second welfare theorems provided neither an accurate description of how actual market 
processes coordinate economic plans, nor of how the institutional environment of the decentralized market generates desirable consequences. Hayek suggested that economists redirect their research program to emphasize the use of dispersed knowledge and the impact of alternative insitutional arrangements on learning. Hayek's theoretical criticisms of standard welfare economics, though, are largely obscured by Grossman and Stiglitz's analysis because it translates Hayek's view of dispersed knowledge into the language of modern formal information theory. This leaves out questions of the context and the tacit dimension of knowledge.

The economic problem, Hayek emphatically stated, was not that posed by standard welfare economics, namely the allocation of scarce resources among competing ends. ${ }^{24}$ This way of stating the problem-which leads the neoclassical mainstream to regard general equilibrium as a solution- "habitually disregards" essential elements of the phenomena under investigation, according to Hayek, by ignoring "the unavoidable imperfection of man's knowledge and the consequent need for a process by which knowledge is constantly communicated and acquired." Equilibrium theorizing is not to be rejected, according to Hayek, but its real purpose must be constantly kept in mind. Formal modeling can be a very good servant, but a poor master; unless we remember that the situation the model describes has little direct relevance for the solution of practical problems, it can lead to mistaken judgement. Hayek constantly reiterated that the equilibrium model "does not deal with the social process at all and that it is no more than a useful preliminary for the study of the main problem" (I945 [I980], 78, 9I).

The essence of the coordinative property of the price system lies not in its ability to convey perfectly correct information about resource scarcity and technological possibilities, but in "its ability to communicate information concerning its own faulty informationcommunication properties" (Kirzner 1985, 196). Disequilibrium relative prices, imperfect as they are, nevertheless provide some guidence in error correction and avoidance. This dynamic process of error detection and correction is absent from formal models of economic "information" premised on static equilibrium.

The informational role of prices goes to the heart not only of Hayek's challenge to economic orthodoxy, but of the particular issue that led Hayek to launch this challenge: the debate over socialism. $^{25}$ 


\section{SOCIALISM REVISITED}

Mises began the debate by pointing out that unlike socialism, capitalism could rely on the information and incentives of the private property order that are manifested in the practice of "economic calculation" based on market prices. Eventually the debate led Hayek to realize that the neoclassical mainstream, as embodied in the socialist economists, was treating economic knowledge as given-not in need of discovery by entrepreneurs. This error is revived by the new information economics, in the sense that it does not recognize the possibility of genuine ignorance. Both the laissezfaire Stigler and the interventionist Stiglitz (et al.) treat knowledge "as if" it exists on a bookshelf, so that the only question is whether it is in one's interest to pull it off the shelf or communicate it accurately to others. Searching for existing, already discovered information is important, but it is not the activity captured in economic calculation. Since Grossman and Stiglitz confuse the "informational" role of prices discussed by Hayek with the pregiven information assumed by static equilibrium models, they misconstrue the socialist calculation debate as pitting capitalism, in which prices allocate resources based upon an imperfect arbitrage process, against socialism, in which the allocation of resources is performed by central administrators but will be imperfect because of the cost of monitoring them.

Once Grossman and Stiglitz questioned the informational efficiency of the price system, then some alternative theoretical framework for assessing economic systems was required. Raaj Sah and Stiglitz (Sah and Stiglitz I985 and 1986) went on to develop an alternative framework for comparing economic systems, continuing the program laid out by Grossman and Stiglitz for examining the comparative costs of different systems of economic coordination. "Informational" questions continue to be at the center of the research agenda, although the focus of comparative assessment is not limited to the informational efficiency of monetary prices. ${ }^{26}$

Armed with their putatively realistic - yet, in fact, static - understanding of economic information, Sah and Stiglitz propose that economists turn to the "quality of decision making" within different organizational structures as the standard of comparison. "How individuals are arranged together affects the nature of the errors made by the economic system," they write (I986, 7I6). In address- 
ing this issue, Sah and Stiglitz begin by postulating that in a market system, if one entrepreneur fails to pursue a profitable opportunity, it is likely that some other entrepreneur will remedy this failure. In a planned economy, though, the decision by the planning board not to pursue a production project rules out its adoption by anyone else. What impact, then, do market and planned economies have on the ability to choose good over bad production projects?

Suppose we have an urn filled with ping-pong balls, each ball corresponding to a production project. In polyarchical economies (markets) we would expect more of both good and bad projects to be chosen. Hierarchical (planned) economies, on the other hand, will choose fewer good projects, but also fewer bad ones. Therefore, according to Sah and Stiglitz, "the incidence of Type I error is relatively higher in a hierarchy, whereas the incidence of Type II error is relatively higher in a polyarchy" (I986, 7I9). Type I error means the rejection of a project that should have been accepted, while Type II error is the acceptance of a project that should have been rejected.

While this exercise is theoretically interesting, it does little to explain the way economic systems actually work. In the real world, Type I and Type II errors are linked and omnipresent. Rejecting a project that should have been accepted allows someone to use the resources freed up by this rejection to pursue a project that should have been rejected. The question, then, is what systemic mechanisms can detect errors of both kinds and can provide information and incentives to correct them. ${ }^{27}$ "An appraisal of the efficiency of the market process," as Kirzner puts it, "involves an appraisal of the way the market process disseminates [the] missing links of information necessary for the discovery of superior opportunities for the allocation of resources" (1963, 30I-302). In making such an appraisal, production projects cannot be treated as essentially known and given. They must be discovered by real-world entrepreneurs operating in specific institutional contexts. The Sah-Stiglitz framework brushes aside any context in which innovation and the discovery of economic information affect economic performance. By viewing economic projects as items in a metaphorical urn, they treat economic information as if it were on the shelf already, such that the only question is how to give people sufficient incentives to get them to pull it off the shelf and use it. This is to ignore the fun- 
damental question raised by Mises and Hayek: how information gets onto the shelf in the first place.

Hayek's insight-supposedly the starting-point of Stiglitz's concern with information (see Stiglitz I994, 6, 24-26) - is that the market process allows us to exploit, utilize, and discover knowledge that had hitherto been unknown to market participants. Entrepreneurs do not choose the optimal production project from an array of known projects; they must discover opportunities for profitable ventures. They must be alert to as-yet overlooked opportunities and exercise good judgment in pursuing them. As Don Lavoie puts it, "the key point of the calculation argument is that the required knowledge of objective production possibilities would be unavailable without the competitive market process" (I985, IO2).

The Sah-Stiglitz framework, by ignoring both the necessary ignorance of economic actors and the corresponding problem of knowledge discovery, directs attention from the questions realworld comparative-systems analysis must ask. The problem is not the establishment of the optimal conditions of competitive equilibrium, but rather the detection of errors-deviations, as it were, from equilibrium. To find such an error is to produce economic information that is useful in a world that does not approximate equilibrium; to use this information in order to make a profit is to move that world a little closer to the normative ideal. A comparison of capitalism and socialism that ignores their systemic ability (or inability) to engage in such error detection and correction is but another exercise in the use of equilibrium to indict reality while ignoring its positive dimension.

Similar difficulties afflict the work of Pranab Bardhan and John Roemer (1992), who argue that the revolutions of 1989 have unjustly discredited the socialist model. The system that failed in I989, they point out, was characterized by public ownership of the means of production; noncompetitive, undemocratic politics; and central command over resource allocation. Bardhan and Roemer offer instead a model of socialism that jettisons central commands and noncompetitive and undemocratic politics, but public ownership remains intact. They interpret public ownership broadly to mean that the political process is in charge of distributing the profits of firms in order to achieve an egalitarian distribution of the economy's surplus. They claim that while a competitive market economy is necessary to achieve the efficient allocation of re- 
sources, private ownership is not a prerequisite for competitive markets.

In Bardhan and Roemer's view, unbridled capitalism generates negative externalities, not the least of which are political. The high degree of ownership concentration under capitalism perversely affects the political process through the influence of the wealthy, they allege. Thus, the efficiency gains of capitalism are offset by the subversion of democracy. Separating economics from politics, and vice versa, is essential to the establishment of a socially harmonious and just system.

The traditional problem with public ownership was the inability to separate political from economic criteria in resource-allocation decisions. Bardhan and Roemer try to avoid this problem by giving firms, not government, the power to allocate resources. But in order to prevent the unequal distribution of wealth, Bardhan and Roemer postulate a model of competition between firms in which property nonetheless remains collectively owned. The real issue, they argue, is competitiveness, not property ownership. The market must be constrained by egalitarian ownership: democracy in distribution, but competition in provision. Concretely, this means the distribution of equal entitlements to firms' profits in the form of shares that can be traded openly, but not cashed in. Shares can only be traded for other shares, not for money. Such a market, according to Bardhan and Roemer, would provide the necessary signals that a capitalist market provides, yet would prevent the concentration of capital.

To Bardhan and Roemer, the key question their model must answer is how to motivate the managers of public firms to act efficiently. They contend that modern research in industrial organization has demonstrated that the owner-entrepreneur model is no longer applicable to capitalist economies. The modern corporation can, however, be disciplined through the capital market and the managerial labor market, so Bardhan and Roemer proceed to replicate them through incentives schemes that tie a manager's reputation and salary to performance and to the distribution of unsaleable shares in their firms. Monitoring has been achieved on the economic front, and political control over the distribution of wealth has been maintained.

The perspective undergirding this model is the Stiglitzian program for recasting economic theory along "informational" lines. If 
one desires a society of change and mobility, then one should choose capitalism. But if stability and security are desired, then one should opt for socialism. Once incomplete and imperfect information are introduced, Chicago-school defenders of the market system cannot sustain descriptive claims of the Pareto efficiency of the real world. Thus, Stiglitz's use of rational-expectations equilibrium assumptions to achieve a more realistic understanding of capitalism than is usual among rational-expectations theorists leads, paradoxically, to the conclusion that capitalism deviates from the model in a way that justifies state action-socialism-as a remedy. ${ }^{28}$

One might well prefer even more realism, however-if one is willing to return to the days when accuracy was more important than mathematical virtuosity. While Stiglitz, Grossman, and Sah admirably introduce realistic elements into the equilibrium framework, that framework remains primary, preventing them from addressing the central issues of the socialist calculation debate. Human fallibility is introduced, but our capacity to adapt to changing conditions and to learn from false starts and ill-fated projects is not. Human imperfection is introduced into the analysis, but only to be condemned by contrast with the equilibrium ideal. Still missing from the analysis is an examination of how imperfect human beings attempt to cope in a real world of ignorance and uncertainty. As a result, we get the bifurcation of the world into a private sector that obeys rational expectations postulates while being unable to do anything to cope with the slightest departure from general equilibrium, and a public sector that, being the creation of the normative equilibrium theorists' imagination, is able to rectify the resulting problems "as if by an invisible hand." As in the earlier Neo-Keynesian synthesis of Paul Samuelson, the gap between norm and reality is closed by the omniscient state.

In Mises and Hayek's analysis, on the other hand, the complex web of institutions and habits that come into existense because of disequilibrium are the object of study. According to Mises and Hayek, legally secured property rights aid social learning in an imperfect real world by encouraging investment, motivating responsible decision making, allowing economic experimentation aimed at error correction, and providing the basis for economic calculation by expanding the context within which price and profit/loss signals can reasonably guide resource use. Formal models of competitive equilibrium, such as Lange's model of socialism, were not able to 
deal with such institutional questions; formal models modified to be superficially realistic, such as Stiglitz's new economics, are equally inadequate. ${ }^{29}$

In the Austrian argument the concrete context within which decisions are made conveys vital information. It is not just that information is costly to obtain, but that it is different information if it is stimulated by a context of rivalrous, private-property exchange. The knowledge actors rely on to make decisions is not universal and abstract, as it must be if it is to be replicated through either bureaucratic planning or political deliberation.

Moreover, in Bardhan and Roemer's model there is no realism, even of a superficial sort, concerning the workings of democracy. In the real world of mass democracies, principal/agent problems (cf. the "state theory" discussed in Evans et al. 1985) are just as real as those facing modern corporations, not to mention problems of preference falsification (Kuran I995) and pervasive ignorance (e.g., Converse I964; see Friedman 1996). Bardhan and Roemer equate political failure with the inequality of influence brought about by the power of money. (This equation is more assumed than proved.) Absent inequalities of wealth, they imagine that effective interest groups could not be formed, so the democratic process would enact the "will of the people." This leaves unexamined the question of the quality of democratic decision making even in the absence of interest groups, and it ignores the possibility that such factors as ideology, personal influence, identity politics, xenophobia, and differential ignorance (e.g., Neuman 1986; Zaller 1992) can be the source of unequal power as easily as money can.

\section{FROM POLITICAL TO ECONOMIC UTOPIANISM AND BACK AGAIN}

Samuelson's synthesis created a rather strange mix of general equilibrium microeconomics with Keynesian macroeconomics. As Robert Lucas repeatedly pointed out in the early I970s, graduate students were taught one thing during their Monday/Wednesday microeconomic theory courses, and another thing on Tuesdays and Thursdays in their macroeconomic theory courses. The link between microeconomics and macroeconomics was supposed to be found in the labor market. But if the labor market was in competi- 
tive equilibrium, this implied that the full-employment output level had been achieved, i.e., that there was no macroeconomic problem.

The circle was squared in Samuelson's Neo-Keynesian model by means of "wage stickiness" and the "money illusion." Unemployment, according to classical economists, was due to wage rigidity caused by labor union or government restrictions on wage adjustments. When there were no such rigidities, then wage cuts could serve to clear the labor market, and widespread, persistent unemployment could not occur. Keynesian economics, however, raised the possibility that unemployment could emerge endogenously in free markets because, first, discoordination between savings and investments in the capital market could produce an effective demand failure that would reinforce pessimistic expectations (see Keynes I936, 245-7I); and, second, because of workers' psychological resistance to nominal pay cuts, and their inability to distinguish nominal from real wages. The second of these problems has, like neoclassical socialism, been taken up by both descriptive and normative equilibrium theorists; indeed, the attack on this aspect of Keynesianism was central in the rise of the Chicago school-and, in turn, to its current displacement by the New Keynesianism.

In the Keynesian system as modeled by Samuelson, workers care about their relative nominal wage rather than their real wage. In bad times, then, workers will resist downward adjustments in relative nominal wages that might bring the labor market into equilibrium. This "stickiness" in wage adjustment makes possible the emergence of an unemployment equilibrium. ${ }^{30}$ Only the tools of monetary and fiscal policy can shift the economy away from such a condition and toward full employment. Workers will be less aggressive in resisting the gradual and indirect downward adjustment of their real wages through inflation than they will in resisting direct downward adjustments of their nominal wages by their employers. Public-policy prescriptions guided by Samuelson's Neo-Keynesian synthesis, then, were predicated on the ability of the government to intervene so as to avoid the excesses of boom and bust and promote economic growth. The interventionist consensus came to be embodied in the idea that there existed a stable tradeoff between inflation and unemployment, and that it was the job of policy makers to negotiate this tradeoff.

The major difficulty with this model was that it relied on an assumption of worker irrationality that was every bit as implausible as 
the hyperrationalistic assumptions with which the Chicago school would soon replace it.

Samuelson's assumption that workers were systematically and repeatedly fooled by the money illusion was less a real synthesis of equilibrium modeling with Keynesian economics than an ad hoc, a priori amendment to the neoclassical microeconomic model of rationally self-interested behavior. As such, it was vulnerable from two directions: either from an Institutionalist attempt to preserve its ad hoc, "empirical" elements at the expense of neoclassical theory (Post Keynesianism; see Davidson 1989 and Prychitko I993), or from a hyperformalist attempt to purify the synthesis by purging it of its Keynesian contaminants. The second route, needless to say, is the one that had the most appeal to a discipline now wedded to formal technique. This explains the astonishing success the Chicago school's "New Classical" economics would have in the I970s in altering the policy agenda of a discipline that had been resolutely interventionist since the Great Depression.

The first shot in the Chicago counterrevolution was Milton Friedman's analysis of adaptive expectations. Next, the Neo-Keynesian synthesis was thoroughly discredited by the development of rational expectations theory. ${ }^{31}$ Samuelson's reconciliation of the microeconomic ideal type with involuntary unemployment was repudiated, along with Keynesian prescriptions, in favor of the view that there could be no involuntary unemployment, hence that government action was unnecessary. The result was a doctrinaire derivation of the laissez-faire conclusions that had been overturned by the formalist revolution; economics was now cleansed of Keynesian impurities that had been introduced in the interest of realism. Equilibrium theory was now used not to indict the market economy, but to insist that it was perpetually in a state of rest. Pressed by the Chicago school for a coherent-formalistic - theory of how reality deviated from equilibrium theory, the Neo-Keynesian synthesis imploded.

Since formalist economics could not model the real-world processes of capitalist adjustment to disequilibrium, economists now had to choose between an irrational world of disequilibrium (original Keynesianism), a rational but unrealistic world of equilibrium (New Classical economics), and an untenable mixture of the two (Neo-Keynesianism). Neo-Keynesian economists, committed to formalism, had tried to fit Keynes's speculations about the failure of 
capitalist economies to maintain full employment into the program of general equilibrium theory. By the I950s, their model had come to represent the intellectual standard of argument to which all economists who wanted to receive a serious professional hearing had to adhere. But Keynes's economics raised questions that were outside the scope of the model. ${ }^{32}$

The Chicago school resolved the tension between Neo-Keynesian theory and reality by insisting that reality must approximate (equilibrium) theory. But since the Chicago school was as committed to formalist methods as the Neo-Keynesians were, it could provide no more of a theoretical explanation of how real-world market economies could approximate full-employment equilibrium than Samuelson could plausibly explain how an unemployment equilibrium came into being. Perfect markets were a presumption, not a conclusion of New Classical economics, just as rigid unemployment was a presumption of Neo-Keynesianism.

The techniques of rational expectations and the development of New Classical economics came to dominate economic thinking in the I970s and I980s. ${ }^{33}$ The assumption of perfect knowledge allowed the New Classicists to interpret all actual ignorance as optimal. Involuntary unemployment could not exist in this model because once search costs were included, the labor market was forever in equilibrium. Disequilibrium was considered incompatible with economic theory. ${ }^{34}$ If someone was unemployed, it must be because she preferred to continue her search for a new job rather than accept work at the prevailing wage.

New Classical economists also sought to place the theory of the business cycle on firm equilibrium foundations. ${ }^{35}$ Robert Lucas's theory of the business cycle presumed that noise in price signals prevented economic actors from distinguishing between changes in relative prices caused by market conditions and changes in the general price level caused by inflation. Increases in the money supply that translated into a change in the general price level should have no effect on the level of output, but if a change in the general price level were misinterpreted by economic actors as a change in relative prices, then the level of output could be distorted by the confusion. In this, the simplest version of Lucas's story, distortions must be caused by unanticipated changes in the money supply. The Chicago school's later "real" —as opposed to monetary-business cycle theory emphasized exogenous factors such as technological change 
and random shocks to explain fluctuations in the aggregate level of output.

The New Classical economics demanded too much. Economic agents were modeled to continually and optimally update their knowledge about the state of the world. In addition, economic agents were assumed to share the monetarist understanding of the effect of monetary policy on the price level. These assumptions gave economic actors the ability to checkmate policy makers. Systematic, rational government intervention was therefore useless. Only unanticipated government policy could affect the aggregate level of output. Despite the flawless precision of this model, it produced a view of the world that was obviously contrary to reality. It is not controversial to insist that real involuntary unemployment, for example, existed during the I930s. Yet the Keynesian explanation of how this phenomenon occurred assumed economic agents without adaptive qualities. ${ }^{36}$ Constrained by the methodological demands of formalism, economists had no way to explain imperfect adaptation to changing economic conditions, so they opted to explain away such imperfections rather than accept them, à la NeoKeynesianism, as brute facts.

The perfect-market assumption and the extreme policy implications of New Classical economics led, in reaction, to the development of the New Keynesian economics and a resurrection of the analytical importance of involuntary unemployment (see Gordon I990 and Summers I990). The New Keynesians sought to provide rational-choice microeconomic foundations for wage and price stickiness. ${ }^{37}$ The first New Keynesian models emphasized nominal rigidities in the price system. In contrast to the New Classical model, which assumed that prices were perfectly flexible, the New Keynesians emphasized that prices are often quite inflexible for a variety of reasons. Real-world labor markets, New Keynesians contended, are often characterized by inflexibility due to the prevalence of long-term contracts, so even if agents have rational expectations, nominal rigidities prevent perfect adjustment and create the need for Keynesian interventionist policies.

However, the early New Keynesian models were criticized by New Classical theorists for lacking a rational-choice foundation for the long-term labor contracts to which they attributed market rigidity. Why would profit-maximizing firms repeatedly lock themselves into long-term contracts that would prove suboptimal at 
some later date? The next generation of New Keynesian models emphasized real rigidities in market adjustment, while retaining the behavioral assumption of rational expectations (or near rationality) throughout the structure of the model. In a world of imperfect information and imperfect market structure, New Keynesian economists such as Stiglitz were able to demonstrate that a non-marketclearing equilibrium could emerge. Thus, real rigidities were capable of generating involuntary unemployment in long-run equilibrium. Furthermore, New Keynesian models were immune from the criticisms leveled against Keynes and the Neo-Keynesians for assuming persistent worker irrationality and misperception of the price level. The New Keynesian models are populated by maximizing agents who suffer no informational disequilibrium, yet who experience involuntary unemployment. This was an intuitively pleasing development because, as Robert Gordon points out, it is evident that unemployed workers and firms are unhappy about their condition. "Workers and firms do not act as if they were making a voluntary choice to cut production and hours worked." 39 Paul Krugman writes that "the new Keynesian idea serves a critically important purpose. During the I970s conservative macroeconomics had Keynesianism on the run with its assertion that it was a logically flawed theory - that it could not be right. The new Keynesian theory showed, on the contrary, that the idea that recessions represent a market failure that can be corrected by government action can indeed be right. This is useful, because in reality Keynesianism is basically right, so it's nice to have a theory that lets us admit it" (Krugman I994, 215).

New Keynesianism is able to achieve this result by means of the efficiency wage theorem. If workers' productivity depends on their wages, it may be rational for employers to offer a wage rate that exceeds the market-clearing level. ${ }^{40}$ They may refuse to lower wages to the market-clearing level, fearful that the productivity of their existing workforce will fall. A higher-than-market-clearing wage may therefore be rational, since workers, realizing that the wage is significantly higher than wages they could obtain by working elsewhere, will work harder, shirk less, quit less often, and be loyal and diligent. ${ }^{41}$ The downside of the higher-than-equilibrium wage, however, is that both unemployed workers and firms face difficulties in bidding down the price of labor. ${ }^{42}$ Too-high wages, and thus involuntary unemployment, are structurally embedded in capitalism. 
This model is, however, as formalistic as its Neo-Keynesian and New Classical predecessors. The New Keynesians raise many interesting questions about market frictions, but since the model of general competitive equilibrium remains the benchmark, the efficiency wage simply replaces the money illusion as an ad hoc, empirically ungrounded dogma purporting to explain why, in an otherwise perfect world that approximates the equilibrium model, inconveniences such as unemployment seem to occur. To be sure, New Keynesianism is an improvement upon the New Classical assumption of the instantanous adjustment of all markets, including the one for labor; the New Keynesians at least take notice of the existence of involuntary unemployment. But their explanation of this phenomenon is inconsistent with even the most cursory examination of the way real-world firms tend to set wages. Everyday experience suggests that high wages are often caused by, rather than being the cause of, talents that are in great demand; and that when demand for a worker's talents slackens, her wages are cut. Such observations reopen the door to explanations of involuntary unemployment in which some exogenous factor renders labor unable to accept wage cuts in order to avoid unemployment, since it would seem that if there is systemic unemployment, something must be disrupting the market's profit-and-loss error-correction mechanism. At this point economics will have parted decisively with New Keynesianism, since the latter view presupposes that the market contains endogenous sources of mass unemployment. ${ }^{43}$

It is entirely possible, of course, that in some firms, industries, or even entire economies, the New Keynesian story will turn out to hold good. But surely the burden is on the spinners of this tale to demonstrate how often it is anything more than speculation; and they have no more discharged this obligation than their New Classical opponents have demonstrated the existence of perfect markets. Instead, the New Keynesians appear to be satisfied with having put rational-choice foundations under Keynes's conviction that market adjustments alone cannot solve unemployment. Like rational-expectations theorists who developed elaborate "proofs" of how the (Neo-)Keynesian picture could not be true, the New Keynesians start with the assumption that it (or something very much like it) must be true, and then try to explain how this "reality," as Krugman puts it, might have come to be. In the end, then, the New Keynesians are as ideological as the Chicago school. In the hands of both, 
economics is reduced to a game in which preconceived notions about the goodness or badness of markets are decked out in spectacular theory. In neither case do economists fulfil the fundamental scientific responsibility of testing the veracity of their explanations.

To make such a serious charge against the two dominant schools of contemporary economics, however, is to do little more than notice the logical implication of their use of the equilibrium model as either a representation of reality or an indictment of it. And this brings us back to the marginalization of the old style of neoclassical economics that took place shortly after Hayek's speech of I933. It was, after all, an ideological impulse - the desire of left-wing economists to justify Keynesian interventionism and socialism-that led to the initial triumph of formalism. These economists needed no persuading that the market had little capacity for self-correction and adjustment to disequilibrium; thus, they treated the state as a deus ex machina that could close the gap between theory and reality. The Chicago school's reaction against this view was equally ideological, for all its scientism; but here the deus ex machina was the market itself. Even while Hayek was seen as ideological because of his inability to make his case in the language of "scientific" formalism, the introduction of this language actually had the effect of licensing any ideological predisposition that could be translated into its terminology.

Both the Chicago school's utopian view of reality and its opponents' dystopian view were given life by the assumption that equilibrium was necessarily intended to be a description of the market. The Chicago school simply affirmed this intention by praising the "magic of the market." The Keynesians, Neo-Keynesians, and New Keynesians also affirmed the intention, but they denied that the resulting description was accurate. They were led, in consequence, to view the model as an ideal that is attainable only by government action; they replaced the magic of the market with the magic of the state. Neither the Keynesians nor the Chicagoans explain how imperfection can be institutionally remedied, rather than circumvented by either market or political actors with heroic capacities.

What both schools overlooked was the fact that equilibrium is a static construction that could not possibly represent a dynamic world of time, ignorance, and uncertainty; but that the divergence between ideal and reality can highlight the ways reality may have institutionalized error-correcting properties that can, in fact, be seen 
as propelling the world in a direction reminiscent of general equilibrium. But like any ideal type, equilibrium is a postulate that is not necessarily effected in the real world. ${ }^{44}$ The main task of any science is to investigate the degree of correspondence between various ideal types and empirical reality; but this means that science is primarily a matter of experimentation or, in social science, historical researchnot model-building but model-testing (i.e., testing of the applicability of intelligible models to given situations). Still, the "falsification" of an ideal type in a given instance does not require that it be discarded as useless. It may aid the scientist in constructing ever more realistic models of the circumstances of that particular time and place. This procedure once allowed economics to be something quite different from an exercise in the provision of rationales for predetermined conclusions.

\section{WHAT WENT WRONG}

I do not claim that economists who followed the ideal-type procedure, such as Hayek, were immune from ideology themselves. But in principle, treating models as ideal types allows one, or one's colleagues, to root out one's ideological prejudices by subjecting one's models to the empirical test of applicability as well as the philosophical test of intelligibility.

This view of ideal-typical science is itself, of course, an ideal type; it will apply more to some scientists or disciplines in some eras, and less to others. Unfortunately, since I933 the trend of Western economic thinking has been to turn this ideal type-and this ideal-into nothing but a pious hope. Despite economists' official adherence to Milton Friedman's methodological positivism, the testing of theories against reality has become less and less central to their activity; instead, the generation of formal models has become an end in itself. ${ }^{45}$ This was virtually inevitable, since the tenets of formalism require that economic argument must be placed in a certain language if it is to be considered scientifically legitimate. ${ }^{46}$

As a result, none of the main centers of economic education convey a theoretical understanding of real-world market institutions. That is not viewed as their educational purpose. D. N. McCloskey (I99I, I2) has pointed out that "economics in American universities has become a mathematical game. The science has been drained out of economics, replaced by a Nintendo game of assumptions ... 
with as much practical payoff as chess or lotto." Instead of producing economists who seek to understand the working properties of economic forces in real historical time, "the graduate schools in economics have been producing scientific illiterates." These are sharp criticisms, but they are more or less on target. Arjo Klamer and David Colander's study, The Making of an Economist (I990), details how the formalist revolution substituted mathematical skill for sensitivity to historical and institutional details, and how students have responded predictably to the internal reward system set up by formalist economics.

The devolution of thought that Hayek perceived at the time he wrote "The Trend of Economic Thinking" provides a useful point of comparison with the present situation. Just as Hayek saw the real danger as residing in the second generation of anti-theoretical economists, the first generation of formalists, having been taught by older economists, still possessed a sense of historical and institutional realism that was absent in the next and subsequent generations. Equilibrium models still had to meet some standard of realism, even if these standards no longer had official methodological legitimacy. Thereafter, however, it was the model, and not the world, that became the dominant source of intellectual excitement. Technique has trumped substance ever since.

As a result of this natural progression of the formalist revolution, a new form of theoretical relativism has emerged. Hayek saw Historicism as providing a relativistic challenge to the analytical claims of classical and neoclassical economics, especially when applied to public policy. Arguments for laissez faire were rejected by Historicists on the grounds that they were based either on faulty assumptions about human nature, or on analysis that may have been true for one period of history, but was irrelevant in another period. But this apparently fact-based, scientific approach did not actually provide empirical evidence that, say, the "laws" of supply and demand were "repealed" in certain historical epochs. To do this, Historicism would have had to explain what motivated observed economic relationships in the absence of such "laws." But, for the most part, no such alternative explanations were forthcoming. Instead, Historicists typically pointed to some phenomenon that seemed on the surface to contradict economic "laws," and then reached the sweeping conclusion that in the face of such phenomena, one should abandon theorizing about them in favor of data collection and policy ad-hocery. This naive empiri- 
cism had the effect of substituting confused, sub rosa theorizing for the careful, refutable theorizing embodied in classical economics and canonized in Weber's method of ideal types. In the guise of repudiating the classical economic assumption that instrumentally rational behavior is an ideal type that is universally instantiated in the real world, Historicism proposed an equally a priori, unscientific theoretical scheme-a scheme of historically determined motivational pluralism unfounded on any rigorous investigation of behavioral evidence-but one that could not even be debated intelligently, since the theoretical claims about a given era were implicit and incoherent.

The formalist revolution generated a similar disregard for empirically meaningful and rigorous theorizing. Ideal-type theorizing had been designed to establish whether real-world processes might explain the movement of disequilibrium phenomena toward an everelusive hypothetical equilibrium. But to render the equilibrium model in mathematical terms, formalists had to view it as a static condition against which disequilibria could only be compared timelessly_or banished as an illusion.

Different formal models generate different conclusions, and since each model is, in principle, equally unable to explain real-world disequilibria, there is no way to choose between them in any absolute sense. Economic arguments against interventionism based on New Classical assumptions could just as easily be false as arguments for intervention based on New Keynesian assumptions could be true. All we have is a succession of logically consistent and very elegant models that say little or nothing about the world-except that anything is possible.

What is true of contemporary macroeconomics is also true for microeconomics. Consider the situation in industrial organization. As Franklin Fisher (I99I) pointed out in a review essay on the Handbook of Industrial Organization, the main organizing principle of modern industrial organization is that there are no organizing principles. Modern theory simply demonstrates that anything can happen, given different assumptions. All of the models are admittedly unrealistic and do not illuminate real situations in the economy. This is viewed as a pragmatic weakness, but not a "theoretical" weakness, since theory has been divorced from reality. The unrealistic simplicity of the models is designed to allow theorists to do complicated mathematics, not to allow testing against reality. Con- 
versely, the empirical analysis that does occur is rarely informed by theory. And any policy preference can be backed up in some vague way by one model or another.

Ironically, the interventionism this allows is a product of the methodology of the arch-laissez faire Chicago school. Samuelson was responsible for transforming economic theory into a branch of applied mathematics, but Milton Friedman must share some of the responsibility for transforming the psychology of economists by means of his seminal I953 Essays on Positive Economics-one of the staples of graduate economic education over the last four decades, along with Samuelson's bible of technical economics.

Friedman argued that an assumption's realism mattered little as long as it could produce positive predictions. Part of what went wrong with economics, it might be argued, is that this testing is the exception rather than the rule (see, e.g., Rosenberg I994). But the problem goes deeper. Even in the wake of formalism, theorists had been constrained by an historical and institutional sensitivity that prevented them from introducing blatantly false assumptions. ${ }^{47}$ Friedman himself, for example, had attacked Abba Lerner's The Economics of Control (I944) for failing to address many of the institutional questions that would arise from using the price system in the absence of private-property ownership. The Economics of Control was economics in a vacuum, according to Friedman, and was not "combined with a realistic appraisal of the administrative problems of economic institutions or of their social and political implications" (I953, 3I9). But just such an appraisal is undermined by Friedman's methodology. All Lerner had done (like Lange before him), after all, was replicate for socialism the unrealistic model assumed to be legitimate for capitalism - the model of perfectly competitive general equilibrium - that Friedman had placed at the foundation of the Chicago school's understanding of economic reality. Change a few assumptions here and there, and it follows that general equilibrium socialism can achieve the same efficiency properties as general equilibrium capitalism. Since real-world capitalism deviates considerably from competitive equilibrium (and is more likely to correspond to monopolistic rather than competitive equilibrium), realworld socialism built on the Lange-Lerner model would outperform capitalism. Yet in his role as comparative systems economist rather than methodologist, Friedman implies that only a seri- 
ous case of confusing mental constructs with empirical reality could result in this judgment.

By the same token, Friedman's famous advocacy of economic laissez faire, unlike that of such later Chicagoans as Gary Becker, is in most cases unconnected to the general equilibrium model. Rather, Friedman's policy outlook is deeply shaped by Hayek's analysis of the informational difficulties of government planning and Hayek's understanding of spontaneous order, combined with James Buchanan's work in public choice theory and constitutional political economy (see, e.g., Milton Friedman 1979). Later economists, however, took Friedman's methodology more seriously than he himself seems to have done. His pragmatic concerns were swept away in favor of elegant formal modelling. The economic world is no longer an object of study; the formal model of an abstract economy is what is of concern to economic scientists. ${ }^{48}$ Thus, Gary Becker $(1976,5)$ defines the economic approach as the relentless and unflinching use of the postulates of maximizing behavior, market equilibrium, and stable preferences. His efficiency claims about the market are predicated on the assumption that these postulates are descriptively accurate, even though they are propositions in comparative statics while the real world is evidently dynamic.

Faced with the kind of criticisms of this view that have been raised by Arrow, Stiglitz, and other market-failure theorists, Chicago economists typically respond by insisting that the real world is in equilibrium when all the appropriate costs are included in the analysis. In other words, the market-failure theorists have made an illegitimate comparison between an ideal state and the imperfect world. Demsetz's attack on the "nirvana fallacy" is an example of this style of Chicago response to suggested market failures. Demsetz argues that Arrow's market failure theory results from an illegitimate chain of reasoning that begins with a deduced discrepancy between the ideal situation and the real situation, which is then transformed into a demand for perfection by the use of an unexamined alternative arrangement. This call for perfection by incantation is guilty of the fallacy of the free lunch, i.e., the belief that the alternative arrangement could be established costlessly (Demsetz I969).

This response, while making an important analytical point about comparative institutional analysis, nevertheless contains a bias in favor of the status quo that Demsetz fails to justify. He implies that 
whatever exists must be efficient; otherwise, change for the better would have already occured. But if the economy were as efficient as Demsetz assumes, many of the phenomena Chicago economists study - including money, firms, and law-would not exist. ${ }^{49}$ Such institutions enable economic processes in the real world to achieve whatever degree of self-correction and economic coordination the formal model of competitive equilibrium was supposed to capture in the first place; yet these institutions come into being only to the extent that equilibrium is not a description of reality, but an ideal type that does not describe reality.

The New Classical economics that emerged in the I970s and I980s displayed the same complacency about the status quo, dismissing involuntary unemployment as theoretically incoherent and empirically void. For involuntary unemployment to be a myth, the New Classical economists posited economic actors who adjusted their behavior so quickly (for all practical purposes, instantly) that equilibrium would be achieved at all points. Compared to this, the New Keynesian efficiency-wage theorem appears the model of sober realism. ${ }^{50}$

New Keynesianism interventionism is nourished by leaks in the supposedly watertight equilibrium theory of the Chicago school. But the arguments for the new interventionism are simply variations on the bad habits that gave rise to the Chicago school. Imperfect market theory, like perfect market theory, is addressed to a model, not to the world the model is supposed to illuminate.

$$
\text { * } \quad * \quad *
$$

Alan Coddington has pointed out that "instead of asking how reason can be applied to the knowledge that men can or do have of their economic circumstances," modern economic theory "asks how reason can be applied to circumstances which are perfectly known." The troublesome problems of "what can be known, and how it can come to be known-problems of ignorance, uncertainty, risk, deception, delusion, perception, conjecture, adaptation and learning - are then tackled as a complication and refinement on the theory" (Coddington 1975, I5I). Modern theorists' static conception of reason is in direct conflict with the passage of real time (O'Driscoll and Rizzo I985, 52-70). The postulates of rational choice theory can only generate formal proofs if the future (with its novelty, uncertainty, and ignorance) is excluded. Modeling that 
excludes this component of reality not just for counterfactual purposes, but as part of realistic attempts to describe or condemn the market, are bound to be insufficient. ${ }^{51}$

This is not, as I have tried to demonstrate throughout this essay, simply a methodological complaint. It has a host of serious implications. The temporal structure of production, for example, with its employment of heterogeneous components to form the various combinations that make up the unique capital structure of a given economy, are excluded from modern analysis. As a result, the way market signals constantly reorganize capital combinations remains invisible to the modern economist. Nor is the impact of monetary price adjustments on the pattern of exchange and production fully incorporated into economic theory: either prices are assumed to represent the underlying information perfectly (competitive equilibrium), or they are assumed to reflect that information so imperfectly that they constitute market failure. In both instances, the informational content of the price system is misrepresented. As should be obvious, this has profound implications for understanding various economic systems and paths of economic development.

The precision of equilibrium modeling is gained at the expense of correspondence with the imprecise world the model was once supposed to help us understand. Paradoxically, the careful expression of imprecise concepts and processes in natural language supplies us with a more accurate picture of the economic world than the most rigorous mathematical modelling. Careful thought requires coherence; relevant thought requires correspondence to reality. Good economics requires both coherence and correspondence.

The often-stated argument that mathematical modeling eliminates ambiguity in thought by forcing theorists to state assumptions explicitly is based on a conflation of the concepts of syntactic and semantic clarity. Mathematical reasoning ensures that modeling is disciplined by syntactic clarity, but semantic ambiguity is the result (see Coddington 1975, I59). The abandonment of mathematical reasoning using equilibrium models would herald a return to semantically rigorous standards of argument about the economic world "out there."

The twentieth century's oscillation between perfect market theory and market failure theory, both of which take as the terms of debate the formal model of general competitive equilibrium, will inevitably be won by theorists of market failure. It is obvious that 
the economic world is not perfectly competitive (or even near that state of affairs). Hence the triumph of the interventionism Hayek forecast - not because economic theory has been rejected, but because it has been misconceived. While Stiglitz and other contemporary market-failure theorists intend to rebut Hayek's analysis of the benefits of the private-property, competitive-price system, in reality their response to Hayek constitutes a non sequitur. ${ }^{52}$ Since Hayek's argument did not depend on the achievement of static equilibrium, the deviations of real markets from the model do not constitute rebuttals to him. Indeed, deviations from the model were Hayek's starting point.

To address Hayek's argument seriously, economists would have to drop the false precision of equilibrium models and engage in careful reasoning about imprecise phenomena, such as the passage of time, the limits of our knowledge, the uncertainty of the future, and the discovery of opportunities. ${ }^{53}$ Perhaps Hayek's argument cannot be sustained when confronted in this manner, but this we will not know until seven decades' worth of disastrous formalization is abandoned and the realities of economic life are re-engaged.

\section{NOTES}

I. Of course, the Austrians were involved in major debates of this era among mainstream economists, notably the capital theory debate (with J. B. Clark) and the value and price theory debate (with Alfred Marshall). These were, however, viewed as intramural analytical, not programmatic, debates. Marginalists were thought to be analytically united, despite differences over subsidary assumptions or even broader issues of pre-analytical vision.

2. Henry Hazlitt's critique of the Keynesian system, presented in The Failure of the "New Economics": An Analysis of the Keynesian Fallacies (1959), argues that many of the fallacies within Keynesianism are the consequence of misunderstanding orthodox doctrine. See also Hazlitt I960.

3. See Skidelsky 1992 for an intellectual biography of Keynes during the time of the writing of The General Theory.

4. Samuelson's hold over economists can be explained on two levels. First, economists suffer from physics envy; Samuelson's mathematization of economics promised to complete the transformation of economics into social physics that was started by Leon Walras. Second, Samuelson was not only smart, but strategic. Shortly after his Foundations became the major textbook in graduate education, Samuelson's Economics became the leading un- 
dergraduate text. Samuelson influenced students on their way in and on their way out. Within a decade, Samuelson became synonymous with economics, and his hold over the style-if no longer the substance-of economic reasoning has not waned since.

5. See Samuelson I947, 203-53, where he discusses welfare economics and the implications of the competitive model. Also see Samuelson I96I, $678-89$ and 8 I $8-36$, for his undergraduate textbook's treatment of the issues related to socialist planning.

6. One of the best examples of this reversal is to consider the interpretive difference between Samuelson and Hayek on the implications of the equilibrium pricing theories of Pareto (I909) and Barone (I908) for collectivist planning. Hayek included a translation of Barone's essay in his Collectivist Economic Planning (1935) precisely because he thought it was clear that Barone demonstrated the practical inability of the collectivist planning system to replicate what is achieved in the competitive market economy. Similarly, Pareto is explicit that the collectivist planner would confront an insurmountable task even in a simple economy, whereas the capitalist system solves the problem of economic calculation every day through the impersonal market process. Both Barone and Pareto, however, demonstrated that in order to achieve economic efficiency in production, collectivism would have to solve the same set of equations as competitive capitalism. In other words, there was a formal similarity in the economic problem in both capitalism and socialism. The recognition of this formal similarity was preliminary to the analysis of the problems that collectivist planning would confront, not their solution. Yet since Samuelson contended that Mises's critique of socialism was refuted in advance by the work of Barone and Pareto, he contended that the collectivist planning system could simply replicate the trial-and-error process explicated by Barone and Pareto. The fact that both Barone and Pareto explicitly denied that such a replication was possible in practice is brushed aside by Samuelson.

7. Besides Samuelson, the most important figures in this transformation of economics were Kenneth Arrow, Gerald Debreu, and Frank Hahn. It is no coincidence that each of these individuals made major contributions to market failure theory in addition to their development of the model of general competitive equilibrium.

8. In perhaps the best intellectual biography of Coase to date, Steven Medema (1994) argues that Coase was concerned with examining the consequences of alternative legal arrangements on economic performance rather than in using economic techniques to examine the law. This difference in emphasis explains Coase's lack of interest in Posnerian law and economics, a movement more concerned with the use of economic techniques to examine the efficiency of various legal arrangements. Coase not only suggested an alternative comparative institutional program of research, but thoroughly questioned the logical coherence of mainstream 
neoclassical economics. Part of the equilibrium exercise that Coase engaged in was to show that pursuing the logic of maximizing within an environment of zero transaction costs led to conclusions different from those suggested by Pigouvian welfare economics. If transaction costs were zero, then economic actors would negotiate away the conflict; if transaction costs (including informational costs) were positive, then how would authorities know what the right level of tax or subsidy should be to correct the situation? Coase's research program entailed both a critique of prevailing practice and a positive alternative program that is now emerging in the New Institutional Economics, of which Coase is still the leading representative.

9. Krugman I995 admits that the development theory of Albert O. Hirschman and Gunnar Myrdal was essentially correct in its emphasis on strategic complementarity in investment, and in using coordination failures to explain why some countries are rich while others remain poor. But these ideas were ignored by economists in the I950s and I960s because they were not properly modeled-which Krugman defends, because only a properly modeled idea deserves serious attention by the profession. Avinash Dixit (1996) makes a simliar argument with respect to the economic theory of politics. It is this attitude among the second and third generation of economists after Samuelson that has come to dominate mainstream economics.

Io. I have addressed this evolution in economic thought in Boettke I996a. Cf. Heilbroner and Milberg I995.

II. Nothing I have said in this paragraph is original to me: See Hirschman I986 and Sen I987. Hirschman has proposed that we complicate economic discourse by recognizing the incredible complexity of human nature, while Sen suggests that we recapture moral philosophy in economic discourse.

I2. Various scholars often blend the different uses. Frank Knight, for example, used equilibrium as an ideal type in his classic Risk, Uncertainty and Profit (I92I), but in The Ethics of Competition (I935) he used it as a critical normative standard. Alfred Marshall is remembered as the pioneer of partial equilibrium analysis (which assumes an overall equilibrium in the economy, but focuses on a particular market), often assumed to be the hallmark of the Chicago-school approach, but we can also read Marshall as an idealtype theorist when he states that equilibrium analysis is preliminary to an "advanced study" that would be more evolutionary in nature (Marshall I920, 269). Nevertheless, even in these cases one can easily distinguish between the various deployments of the equilibrium construct.

I3. See Jeffrey Friedman I995 for this version of Weber's methodology of ideal types. Cf. Weber [1956] I978, 9-I2. Machlup 1978, 207-30I discusses the ideal-type methodology as applied to economics in general. Cf. Weber [1956] I978, IO, on 'the 'imaginary experiment' which consists in thinking away certain elements of a chain of motivation and working out the course of action which would then probably ensue, thus arriving at a 
causal judgment." Mises (I949, 236-37) describes this approach as "the method of imaginary construction." Cf. Hayek I940, I4-28.

I4. Those inclined toward the descriptive use of equilibrium basically deny that these seemingly complex problems exist in the world. Philosophically, the argument relates back to the ancient assertion that change is an illusion. On the other hand, those who use equilibrium as an indictment of reality view the existence of a problem as, by definition, evidence that the ideal solution of competitive equilibrium is obtainable somehow. If the market does not attain perfection, then the state must be capable of it.

I5. The relevant papers by Hayek are collected in Hayek [I948] I980.

I6. In "Economics and Knowledge," Hayek argues that the pure logic of choice is a necessary, though not sufficient, component of an explanation of systematic economic coordination. An understanding of economic coordination requires an empirical understanding of learning. Hayek's research program for economics would have shifted it from the determination of optimal resource use under given conditions to the exploration of the impact of alternative institutional environments on learning.

I7. Picking up a theme first raised by Oskar Morgenstern, Hayek emphasized that perfect foresight was a defining characteristic of equilibrium but not a precondition that must be present for equilibrium to be obtained. Logically, in fact, what Morgenstern had demonstrated was that if economic agents possessed perfect foresight, then a determinate equilibrium solution would evade them. As Joan Robinson also emphasized, the only way to acheive an equilibrium would be to already be in equilibrium-no process toward equilibrium could be articulated on the basis of a theory of perfect foresight. The implication for Hayek of this theoretical conundrum was that economists should focus attention not on the state of equilibrium, but on dynamic adjustment and learning through time. "A theory which starts out by assuming that adjustments have proceeded to the point where no further changes are required," Hayek stated, "is without relevance to our problems. What we need is a theory which helps us to explain the interrelations between the actions of different members of the community during the period (which is the only period of practical importance) before the material structure of productive equipment has been brought to a state which will make an unchanging, self-repeating process possible" (I940, I6-I7).

I8. Kirzner 1997 is an examination of how the theory of entrepreneurial learning fits into this research program and contrasts with standard price theory. Fisher 1983 is a discussion by a leading equilibrium theorist of the necessity of disequilibrium foundations for equilibrium economics. A theory of convergence to equilibrium, according to Fisher, has to be developed, not assumed.

I9. On the theory of search, in contrast to the Austrian view of the market process, see High I990, 28-36 and 83-I24.

20. This line of literature explored information/communication and motiva- 
tional questions associated with the structure of incentives. The main conclusion was that decentralization was less important than incentives. But the version of decentralization explored in these models was far different from Hayek's hypothesis about the use of knowledge in society, even though Hayek was supposed to be the starting point of this literature.

2I. Information economics led economists to investigate agency costs, informational asymmetries, strategic interaction, and organizational design. These are all important problems, but the models developed to explore them arguably fail to capture how real-world adjustment processes deal with them.

22. For overviews of this work in information-theoretic research in economics see Stiglitz 1994 and Grossman 1989. A textbook-style treatment of information-theoretic economics in general can be found in Campbell I995. An Austrian critique of the Stiglitz-Grossman program can be found in Thomsen I992. For critical discussion of Stiglitz I994 see Boettke I996b and Prychitko I996.

23. The strong assumption of rational expectations had become by the midI970s common in all models.

24. Buchanan [1964] I979, I7-37, also forcefully argues that economists should concentrate their efforts on exchange relationships and the various institutional arrangements that result from these relationships, rather than equilibrium states, placing Buchanan alongside Mises and Hayek and earlier thinkers such as Richard Whateley. Also see Kirzner I973, 212-42.

25. There has been some debate over the relative importance of Mises's calculation argument and Hayek's knowledge problem. But they seem to me to be two sides of the same coin. Calculation without knowledge is oxymoronic, and knowledge without the ability to do economic calculation is unimportant. Private property and monetary calculation are the means by which the knowledge problem can be solved in complex economies. That is the argument Mises's and Hayek's critiques of socialism shared, despite their differences of emphasis. As Mises points out in Liberalism, the "decisive objection that economics raises against the possibility of a socialist society [is that] it must forgo the intellectual division of labor that consists in the cooperation of all entrepreneurs, landowners, and workers as producers and consumers in the formation of market prices" (Mises [I927] I985, 75). See Boettke I996c for further discussion.

26. The informational content of a multitude of market practices, not just monetary prices, is recognized by Hayek and others in the Austrian tradition, such as Fritz Machlup. Stiglitz's attempt to remedy the unrealistic nature of descriptive equilibrium by paying attention to information is doomed to failure because information is dynamic, yet formalism renders it inherently static.

27. See Boettke I993, I35-38.

28. Stiglitz does demonstrate the sensitivity of general equilibrium results to initial assumptions. Even rational expectations models do not yield 
Chicago-type efficiency conclusions once slight changes in the initial assumptions are made as (half-hearted) concessions to realism.

29. Lange, for example, accused Mises of "institutionalism" for suggesting that the ability to engage in rational economic calculation was related to a specific institutional context, namely private property in the means of production. See Lange I939, 62 n 6 . Stiglitz I994, I74-75, also doubts the importance of private property in influencing economic performance.

30. Equilibrium here is defined in its classical sense: a state of affairs where there are no endogenous forces that will change the existing state of affairs. Defining the equilibrium state was fundamental to the Keynesian project. As Franklin Fisher writes: "The central question which Keynes sought to answer in The General Theory of Employment, Interest and Money was that of whether (and how) an economy could get stuck at an underemployment equilibrium. To show this, it is not enough to show that such an equilibrium exists, we must also show that it has at least local stability properties so that an economy that gets close enough to such a point will not escape from it without an exogenous change in circumstances" (Fisher I983, 9).

3I. Friedman's theory of adaptive expectations was actually his last in a long line of criticisms of the Keynesian analytical and public policy system. His work on consumption theory had questioned the behavioral premise of the Keynesian theory of consumption, his work on the quantity theory of money challenged Keynesian monetary theory, and his work on rules versus discretion raised doubt about Keynesian fine-tuning.

32. Keynes's theory of the failure of modern capitalism relied on cultural and psychological factors as much as economic ones. The emergence of the much-vaunted "casino" character of the stock market was, according to Keynes, a result of a change in the culture (and the population pool) of trading. In the nineteenth century, more civilized and cultured traders guarded against wide swings due to animal spirits. In the twentieth century, however, old habits evaporated and with them breaks against the wild tides of optimism and pessimism. The interventionist policies Keynes advocated to correct for market breakdown were predicated on the assumption that those in government would be in a better position to assess the efficiency of capital investment (especially in the long term) than those trapped in the hustle and bustle of current market behavior.

33. For a collection of the main papers see Lucas and Sargent I98I. Also see Snowdon, Vane, and Wynarczyk I994, I88-2 I8; and Hoover I994.

34. See, for example, Lucas's interview in Klamer 1984. This dismissal of disequilibrium theory aborted not only the development of traditional Keynesian analysis, but also the work of Clower and Leijonhufvud, Post Keynesian analysis of the sort done by Paul Davidson, as well as Austrian economics. Fisher has characterized Lucas's position "always-clearing markets." When one takes this position, equilibrium analysis does not need any justification. Movements of actual market prices are to be analyzed as a se- 
quence of temporary equilibria. Price offers are instantly adjusted to the short-run equilibrium point. See Fisher $1983,5-6$.

35. When Lucas first articulated an equilibrium theory of the business cycle he would often cite Hayek (a recent Nobel Laurate at the time) as a precursor of his approach. Hayek did, in fact, insist that Keynesians had committed an error by not developing an equilibrium theory of the business cycle. But what Hayek meant was that one cannot offer an explanation of unemployment unless one begins in a state of full employment and explains why the unemployment resulted in the first place. In the system articulated by Keynes and his early followers, full employment was denied at the start of analysis - one began with unemployment (idle resources). Hayek used the equilibrium state of full employment only as a preliminary to the real analysis, which was to explain how unemployment may emerge. Hayek's position, then, was in direct opposition to both Keynes and Lucas. Keynes assumes what needs to be explained, and Lucas treats equilibrium not only as the beginning, but also the end, of his analysis.

36. One of the problems with the Keynesian system was the lack of symmetry in the motives and behavior attributed to economic agents, as opposed to the economist-experts who would fine-tune the economy. Economic agents were assumed to be irrational and self-interested, whereas government policy-makers were presumed to be completely rational and public spirited. Like all ideal types, this one might be found to represent reality in a given time and place; but this needs to be proved, not assumed. Otherwise the theorist can simply predetermine policy conclusions by manipulating assumptions.

37. For a collection of the main papers in New Keynesian thought see Mankiw and Romer I99I. Also see Snowdon, Vane, and Wynarczyk I994, 286-330; and Keenan I994. One of the crucial differences between New Classical and New Keynesian models can be found in the assumption of price taking behavior within the New Classical models and price making monopolistic behavior within the New Keynesian models.

38. As Samuelson emerged as the central figure in the formalist revolution, Stiglitz is emerging as the central figure in contemporary economics. Not only does Stiglitz's work, like Samuelson's, dominate the graduate curriculum, but he has published an introductory-level textbook, Economics (I993), summarizing the extent of his vast contributions to economics for a new generation of students. Just as Samuelsonianism defined economics from the I950s through the I970s, Stiglitzian economics is likely to dominate economic thinking and education from now until well into the twenty-first century. Stiglitz's influence has also been more direct, as he has served as the chief economist in the President's Council of Economic Advisors and the World Bank. Many Stiglitz-inspired arguments have been deployed in policy debates over intervention in the health-care industry (adverse selection), banking (adverse selection and moral hazard), and antitrust (imperfect competition). 
The effect of Stigliz's influence is to make economics even more presumptively interventionist than Samuelson preferred. Samuelson treated market failure as the exception to the general rule of efficient markets. But the Greenwald-Stiglitz theorem posits market failure as the norm, establishing "that government could potentially almost always improve upon the market's resource allocation." And the Sappington-Stiglitz theorem "establishes that an ideal government could do better running an enterprise itself than it could through privatization" (Stiglitz I994, I79)

39. As quoted in Snowdon, Vane, and Wynarczyk I994, 288.

40. In other words, the causation implied in the marginal productivity theory of wages is reversed in the efficiency wage theorem. Rather than workers being paid according to their marginal productivity, they are productive according to what they are paid.

4I. Potential employees are assumed to know more about their work skills and personal qualities than employers. Since the costs of hiring and firing are not trivial, firms are concerned about hiring people they will have to eventually let go because of low productivity. In this situation, the New Keynesian model suggests that applicants who offer to work for less than the efficiency wage will send a signal that they are low-productivity workers. This is a version of adverse selection.

42. Unemployed workers are seen as unable to bid wages down for a variety of reasons that have been summarized as the advantages of insiders (incumbent workers) over outsiders (unemployed workers). The cost of replacing insiders with outsiders is often quite high, including fitting the outsiders into the insiders' work environment if the insiders perceive the threat of wage cuts from the outsiders.

43. Cf. Bellante I994.

44. In this paragraph I follow Jeffrey Friedman I996a, I6ff, which elaborates a Weberian, particularistic methodology; but I disagree with ibid., 9, which blames preformalist economics for assuming, rather than investigating, the correspondence of its ideal types with reality.

45. Cf. Jeffrey Friedman I996a, I2-I3; Mayer I993.

46. After the I940s, as Robert Solow puts it, "judicious discussion is no longer the way serious economics is carried out" (I997, 42). Model-building has become the standard intellectual exercise.

47. Unless, of course, the purpose of the introduction of such assumptions was to engage in a counterfactual mental experiment.

48. In the new interventionism, one set of assumptions (optimal search, perfect competition, etc.) is replaced by another (asymmetric information, imperfect competition, etc.) and the logical results are derived. The model, not the economy, is the subject under investigation.

49. This, for example, is why Coase is to be contrasted with Stigler or Becker or Posner. The starting point of Coase's analysis was that in general equilibrium the phenomena he sought to illuminate would be absent. The causes of the phenomena must therefore be found in deviations from equi- 
librium-in Coase's case, positive transaction costs. In Mises I949, this method of contrast is employed throughout to illustrate the functional significance of various market insititutions in a non-equilibrium world of change. By exploring the logic of a world free of change, one can by way of contrast explore the world of change, which would be too complex to examine directly without the help of this mental tool.

50. The same can be said of the direction in which research on market socialism is going. At the moment these models are not as well worked-out as the New Keynesian models. But in the work of Roemer the key issue is one of mechanism design and determining the appropriate monitoring/ contractual relationship to align incentives. In short, Roemer is trying to use the rational choice equilibrium framework to solve the problems associated with market socialism. As New Keynesian models increasingly question the efficiency of financial and labor markets under capitalism, the need for Roemerian solutions appears to grow, just as in the I930s and I940s the socialist models had a parasitic relationship to Keynesianism.

5I. A great deal of contemporary economics refines traditional theory by incorporating more realistic situations, such as increasing returns, multiple equilibria, and findings from experimental economics. In a recent survey of modern economic theory, David Kreps (I997) contends that these developments (especially experimental economics) have the potential of making economics relevant to reality. But, like market failure theory, the point of much of this work is to demonstrate how real-world behavior deviates from the standard equilibrium model. The standard model remains the point of reference, so the passage of time, the generation of new knowledge, and changing conditions have yet to be incorporated.

52. See, for example, Stiglitz I994, 24-26 and 269-77. Also see John Roemer's I995 essay review of Stiglitz's book, which he refers to as "An AntiHayekian Manifesto."

53. As Karen Vaughn (I994, I78) concludes in her book on the migration of the Austrian school to America, "It seems indisputable that scientific understanding would be much improved if at some point in the future we could genuinely and intelligently say, along with Milton Friedman, there is no such thing as Austrian economics, only good economics and bad economics. But this time we would mean that good economics was an economics not only of preferences and constraints, but also an economics of time and ignorance."

\section{REFERENCES}

Bardhan, Pranab, and John Roemer. 1992. "Market Socialism: A Case for Rejuvenation." Journal of Economic Perspectives 6 (Summer).

Bardhan, Pranab, and John Roemer, eds. 1993. Market Socialism: The Current Debate. New York: Oxford University Press. 
Barone, Enrico. I908. "The Ministry of Production in the Collectivist State." In Hayek 1935 .

Becker, Gary. 1976. The Economic Approach to Human Behavior. Chicago: University of Chicago Press.

Bellante, Don. I994. "Sticky Wages, Efficiency Wages, and Market Processes." Review of Austrian Economics 8.

Boettke, Peter J. I992. "Analysis and Vision in Economic Discourse." Journal of the History of Economic Thought I4 (Spring).

Boettke, Peter J. I993. Why Perestroika Failed: The Politics and Economics of Socialist Transformation. New York: Routledge.

Boettke, Peter J. I995. "Hayek's The Road to Serfdom Revisited: Government Failure in the Argument against Socialism." Eastern Economic Journal 25 (Winter).

Boettke, Peter J. I996a. "What Is Wrong with Neoclassical Economics (And What Is Still Wrong with Austrian Economics)." In Fred Foldvary, ed., Beyond Neoclassical Economics. Aldershot, England: Edward Elgar.

Boettke, Peter J. I996b. Review of Joseph Stiglitz, Whither Socialism. Journal of Economic Literature (March).

Boettke, Peter J. I996c. "Economic Calculation: The Austrian Contribution to Political Economy." Mimeo.

Boettke, Peter J., ed. I994. The Elgar Companion to Austrian Economics. Aldershot, England: Edward Elgar.

Boettke, Peter J., and David L. Prychitko, eds. I994. The Market Process: Essays in Contemporary Austrian Economics. Aldershot, England: Edward Elgar.

Buchanan, James M. [1964] I979. "What Should Economists Do?” In idem, What Should Economists Do? Indianapolis: Liberty Press.

Caldwell, Bruce. I988. "Hayek's 'The Trend of Economic Thinking." Review of Austrian Economics 2.

Caldwell, Bruce. I989. "Austrians and Institutionalists: The Historical Origins of their Shared Characteristics." Research in the History of Economic Thought and Methodology 6.

Campbell, Donald. I995. Incentives: Motivation and the Economics of Information. New York: Cambridge University Press.

Coase, Ronald. 1988. The Firm, the Market and the Law. Chicago: University of Chicago Press.

Coddington, Alan. 1975. "Creaking Semaphore and Beyond: A Consideration of Shackle's 'Epistemics and Economics." British Journal of the Philosophy of Science 26.

Converse, Philip E. I964. "The Nature of Belief Systems in Mass Publics." In David E. Apter, ed., Ideology and Discontent. New York: Free Press.

Davidson, Paul. I990. "The Economics of Ignorance or Ignorance of Economics?" Critical Review 3(3-4): 467-87.

Demsetz, Harold. I969. "Information and Efficiency." Journal of Law and Economics (March). 
Dixit, Avinash. 1996. The Making of Economic Policy: A Transaction-Cost Politics Perspective. Cambridge, Mass.: MIT Press.

Evans, Peter B., Dietrich Rueschmeyer, and Theda Skocpol, eds. I985. Bringing the State Back In. New York: Cambridge University Press.

Fisher, Franklin. 1983. Disequilibrium Foundations of Equilibrium Economics. New York: Cambridge University Press.

Fisher, Franklin. I99I. "Organizing Industrial Organization: Reflections on the Handbook of Industrial Organization." Brookings Papers: Microeconomics.

Friedman, Jeffrey. I995. "Economic Approaches to Politics." Critical Review 9 $(\mathrm{I}-2)$ : I-24.

Friedman, Jeffrey. I996a. "Introduction: Economic Approaches to Politics." In idem ed., The Rational Choice Controversy: Economic Models of Politics Reconsidered. New Haven: Yale University Press. Adapted from Friedman I995.

Friedman, Jeffrey. I996b. "Public Opinion and Democracy." Critical Review Io (I): i-xii.

Friedman, Milton. I953. Essays in Positive Economics. Chicago: University of Chicago Press.

Friedman, Milton. I979. Free to Choose. New York: Harcourt Brace Jovanovich.

Garrison, Roger. I984. "Time and Money.” Journal of Macroeconomics (Spring).

Gordon, Robert. I990. "What is New-Keynesian Economics?” Journal of Economic Literature 28 (September).

Grossman, Sanford. I976. "On the Efficiency of Competitive Stock Markets Where Traders Have Diverse Information.” Journal of Finance (May).

Grossman, Sanford. I989. The Informational Role of Prices. Cambridge, Mass.: MIT Press.

Grossman, Sanford, and Joseph Stiglitz. I976. "Information and Competitive Price Systems.” American Economic Review 66 (May).

Grossman, Sanford, and Joseph Stiglitz. I980. "On the Impossibility of Informationally Efficient Markets." American Economic Review 70 (June).

Hayek, F. A. I933. "The Trend of Economic Thinking.” In Hayek I99I.

Hayek, F. A., ed., I935. Collectivist Economic Planning. London: Routledge.

Hayek, F. A. I937. "Economics and Knowledge.” In Hayek I948.

Hayek, F. A. I944. The Road to Serfdom. Chicago: University of Chicago Press.

Hayek, F. A. I945. "The Use of Knowledge in Society." In Hayek I948.

Hayek, F. A. I948. Individualism and Economic Order. Chicago: University of Chicago Press.

Hayek, F. A. I973. Law, Legislation and Liberty, vol. I: Rules and Order. Chicago: University of Chicago Press.

Hayek, F. A. I99I. The Collected Works of F.A. Hayek, vol. 3: The Trend of Economic Thinking. Chicago: University of Chicago Press.

Hazlitt, Henry. 1946. Economics in One Lesson. New York: Harper \& Brothers.

Hazlitt, Henry. 1959. The Failure of the "New Economics." Princeton: Van Nostrand. 
Hazlitt, Henry, ed. 1960. The Critics of Keynesian Economics. Princeton: Van Nostrand.

Heilbroner, Robert, and William Milberg. I995. The Crisis of Vision in Modern Economic Thought. New York: Cambridge University Press.

Hicks, John. I967. “The Hayek Story.” In idem, Critical Essays in Monetary Theory. Oxford: Clarendon Press.

High, Jack. 1990. Maximizing, Action, and Market Adjustment: An Inquiry into the Theory of Economic Organization. Munich: Philosophia Verlag.

Hirschman, Albert O. I986. "Against Parsimony: Three Easy Ways of Complicating Some Categories of Economic Discourse." In idem, Rival Views of Market Society. Cambridge, Mass.: Harvard University Press.

Hoover, Kevin. I994. “New Classical Economics.” In Boettke I994.

Keenan, Sean. I994. “New Keynesian Economics.” In Boettke I994.

Keynes, John Maynard. [1936] 1964. The General Theory of Employment, Interest, and Money. New York: Harcourt Brace Jovanovich.

Kirzner, Israel M. I963. Market Theory and the Price System. Princeton: Van Nostrand.

Kirzner, Israel M. I973. Competition and Entrepreneurship. Chicago: University of Chicago Press.

Kirzner, Israel M. I979. Perception, Opportunity and Profit. Chicago: University of Chicago Press.

Kirzner, Israel M. I984. "Economic Planning and the Knowledge Problem." Cato Journal 4 (Fall).

Kirzner, Israel M. 1985. "Prices, the Communication of Knowledge, and the Discovery Process." In Kurt Leube and Albert Zlabinger, eds., The Political Economy of Freedom: Essays in Honor of F. A. Hayek. Munich: Philosophia Verlag.

Kirzner, Israel M. 1987. "The Economic Calculation Debate: Lessons for Austrians." Review of Austrian Economics 2.

Kirzner, Israel M. I992. The Meaning of Market Process. New York: Routledge.

Kirzner, Israel M. I997. "Entrepreneurial Discovery and the Competitive Market Process: An Austrian Approach." Journal of Economic Literature 35 (March).

Klamer, Arjo. 1984. Conversations with Economists. New York: Rowman and Littlefield.

Klamer, Arjo, and Colander, David. I990. The Making of an Economist. Boulder: Westview.

Knight, Frank. [1921] I97I. Risk, Uncertainty and Profit. Chicago: University of Chicago Press.

Knight, Frank. [1935] I95I. The Ethics of Competition. New York: Augustus M. Kelley.

Kreps, David. I997. "Economics-The Current Position.” Daedalus (Winter).

Krugman, Paul. I994a. The Age of Diminished Expectations: U.S. Economic Policy in the 1990s. Cambridge, Mass.: MIT Press.

Krugman, Paul. I994b. Peddling Prosperity. New York: Norton. 
Krugman, Paul. I995. Development, Geography, and Economic Theory. Cambridge, Mass.: MIT Press.

Kuran, Timur. I995. Private Truths, Public Lies. Cambridge, Mass.: Harvard University Press.

Lange, Oskar. [1939] I970. "On the Economic Theory of Socialism.” In Benjamin Lippincott, ed., On the Economic Theory of Socialism. New York: Augustus M. Kelley.

Lavoie, Don. I985. Rivalry and Central Planning. New York: Cambridge University Press.

Lerner, Abba. I944. The Economics of Control. London: Macmillan.

Lucas, Robert, and Thomas Sargent, eds. I98I. Rational Expectations and Econometric Practice. 2 vols. Minneapolis: University of Minnesota Press.

Machlup, Fritz. 1978. Methodology of Economics and Other Social Sciences. New York: Academic Press.

Mahovec, Frank. I995. Perfect Competition and the Transformation of Economics. New York: Routledge.

Mankiw, Gregory, and David Romer, eds. I99I. New Keynesian Economics. 2 vols. Cambridge, Mass.: MIT Press.

Marshall, Alfred. 1920. Principles of Economics. Philadelphia: Porcupine Press.

Mayer, Thomas. I993. Truth versus Precision in Economics. Aldershot, England: Edward Elgar.

McCloskey, D. N. I99I. “The Arrogance of Economic Theorists." Swiss Review of World Affairs (October).

McCloskey, D. N. I996. The Vices of Economists, The Virtues of the Bourgeoisie. Amsterdam: Amsterdam University Press.

Medema, Steven. I994. Ronald H. Coase. New York: St. Martin's Press.

Mises, Ludwig. [1912] I980. The Theory of Money and Credit. Indianapolis: Liberty Classics.

Mises, Ludwig. I920. "Economic Calculation in the Socialist Commonwealth." In Hayek I935.

Mises, Ludwig. [1922] 198I. Socialism: An Economic and Sociological Analysis. Indianapolis: Liberty Classics.

Mises, Ludwig. [1927] 1985. Liberalism. Irvington-on-Hudson, N.Y.: Foundation for Economic Education.

Mises, Ludwig. [1933] I98I. Epistemological Problems of Economics. New York: New York University Press.

Mises, Ludwig. I944. Omnipotent Government. New Haven: Yale University Press.

Mises, Ludwig. [1949] I966. Human Action: A Treatise on Economics, 3 rd rev. ed. Chicago: Henry Regnery.

Neuman, W. Russell. 1986. The Paradox of Mass Politics: Knowledge and Opinion in the American Electorate. Cambridge, Mass.: Harvard University Press.

O'Driscoll, Gerald P., and Mario J. Rizzo. 1985. The Economics of Time and Ignorance. New York: Basil Blackwell. 
Pareto, Vilfredo. [1909] I97I. Manual of Political Economy. New York: Augustus M. Kelley.

Prychitko, David L. I993. "After Davidson, Who Needs the Austrians? Reply to Davidson." Critical Review 7(2-3): 37I-80.

Prychitko, David L. I996. Review of Joseph Stiglitz, Whither Socialism? Cato Journal I6 (Fall).

Roemer, John. I994. A Future for Socialism. Cambridge, Mass.: Harvard University Press.

Roemer, John. I995. “An Anti-Hayekian Manifesto.” New Left Review (May/June).

Rosenberg, Alexander. 1992. Economics-Mathematical Politics or Science of Diminishing Returns? Chicago: University of Chicago Press.

Rothbard, Murray. 1962. Man, Economy and State. 2 vols. Princeton: Van Nostrand.

Sah, R. K., and Joseph Stiglitz. I985. "Human Fallibility and Economic Organization." American Economic Review 75 (May).

Sah, R. K., and Joseph Stiglitz. I986. "The Architecture of Economic Systems." American Economic Review 76 (September).

Samuelson, Paul. I947. Foundations of Economic Analysis. Cambridge, Mass.: Harvard University Press.

Samuelson, Paul. I961. Economics. New York: McGraw-Hill.

Sen, Amartya. 1987. On Ethics and Economics. Oxford: Blackwell.

Skidelsky, Robert. I992. John Maynard Keynes: The Economist as Savior, 1920-1937. New York: Penguin.

Smith, Adam. [1776] 1937. An Inquiry into the Nature and Causes of the Wealth of Nations. New York: Modern Library.

Snowdon, Brian, Howard Vane, and Peter Wynarczyk. I994. A Modern Guide to Macroeconomics: An Introduction to Competing Schools of Thought. Aldershot, England: Edward Elgar.

Solow, Robert. I997. "How Did Economics Get That Way and What Way Did it Get?" Daedalus (Winter).

Stigler, George. I96r. "The Economics of Information.” Journal of Political Economy (June).

Stiglitz, Joseph. I993. Economics. New York: Norton.

Stiglitz, Joseph. I994. Whither Socialism? Cambridge, Mass.: MIT Press.

Summers, Lawrence. I990. Understanding Unemployment. Cambridge, Mass.: MIT Press.

Thomsen, Esteban. 1992. Prices and Knowledge: A Market-Process Perspective. New York: Routledge.

Vaughn, Karen. I994. Austrian Economics in America: The Migration of a Tradition. Cambridge: Cambridge University Press.

Weber, Max. [1956] 1978. Economy and Society: An Outline of Interpretive Sociology, vol. 1. Ed. Guenther Roth and Claus Wittich. Berkeley: University of California Press.

Zaller, John. I992. The Nature and Origins of Mass Opinion. Cambridge: Cambridge University Press. 